\title{
中国における標準日気象データと暖冷房設計用気象デー夕に関する研究 STUDY ON THE TYPICAL WEATHER DAY AND THE WEATHER DATA FOR BUILDING THERMAL DESIGN IN CHINA
}

\author{
張 晴 原*, 浅野賢二**, 林 徹夫*** \\ Qingyuan ZHANG, Kenji ASANO and Tetsuo HAYASHI
}

\begin{abstract}
In this study, the Typical Weather Day data for the simulations of buildings were developed following the previous study on the Typical Weather Year data for some main Chinese cities. Using the date-base of interpolated observation weather data, the heating degree-days and cooling degree-hours were calculated for the main cities in China. It was proved that the air-conditioning loads of a residence can be calculated by the average elements like dry bulb temperature, humidity, solar radiation, wind speed and cloud amount. The monthly average weather data for each hour were defined as the typical weather data for the month by the authors. The Typical Weather Day data for the main cities in China were given. Finally, the weather data for the thermal design of buildings were developed with the TACs of $2.5 \%$ and $5.0 \%$.
\end{abstract}

Keywords: Heating degree-days, Cooling degree-hours, Typical Weather Day, Weather data for thermal design 暖房ディグリーデー，冷房ディグリーアワー，標準日気象データ，暖冷房設計用気象データ

1. はじめに

中国の住宅におけるエネルギ一消費量を予測するためには，熱挙 動シミュレーション用気象データが不可欠である。著者らは中国の 46 都市における標準年気象デー夕を作成し，それを用いて中国の暖 冷房負荷の地域特性を解明している 1),2),3)。このような標準年気象デ 一タは住宅の熱挙動のシミュレーションを行う際大変有意義である が, デー夕は膨大であるうえ，それを用いて負荷計算を行うと，標 準月における各気象要素の平均值からの乘離によって, 標準年気象 データで得られる空調負荷は必ずしも累年平均値と一致するとは限 らない。このような問題を解決するために, 各月の代表的な標準日 気象デー夕を作成すれば，住宅の暖冷房負荷の解析に意義があると 思われる。また，暖冷房設備を設計する際，夏季および冬季の危険 率別の温湿度が必要であるが, 中国の各地における暖冷房設備を設

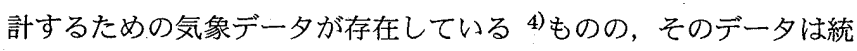
計的な根拠が明らかでないうえ，外気温度の日变動パターンも不明 であるため，設備設計に不十分である。

そこで, 本研究では標準日気象デー夕と設備設計用気象デー夕を 作成することを目的とする。まず, 1982 1997 年の間の観測気象デ 一夕に基づいて中国 46 都市における暖房ディグリーデーと冷房デ イグリーアワーを求めた。次に, 各地の時刻別乾球温度, 相対湿度,
水平面全天日射量, 風速および雲量の月平均値を求め, その地点の 当該月の標準日気象データとした。最後に, 危険率 $2.5 \%$ と $5.0 \%$ の 時刻別乾球温度と絶対湿度を求め, 暖冷房設計データとした。

\section{2. 各地における暖房ディグリーデーと冷房ディグリーアワー} 地域の気候特性の検討や建物の熱設計を行う際, 暖房ディグリー デーおよび冷房ディグリーアワーは重要な基礎資料である。中国の 主要都市において $5{ }^{\circ} \mathrm{C}$ を暖房開始温度とする暖房ディグリーデーの データが存在する 4)ものの, 冷房ディグリーデーあるいは冷房ディ グリーアワーに関するデー夕は皆無である。また, 既存の暖房ディ グリーデーデータは $5{ }^{\circ} \mathrm{C}$ 暖房開始温度としており, 熱容量の大き いレンガ造または RC 造が主流であるとはいえ, 生活水準が急速に 改善している今では, やや低すぎると思われる。したがって, 本研 究では $5^{\circ} \mathrm{C}, 10^{\circ} \mathrm{C}, 15^{\circ} \mathrm{C}$ 開始温度とした暖房ディグリーデーおよ び $23^{\circ} \mathrm{C}$ 開始温度とした冷房ディグリーアワーを求めた。

実際の住宅暖房設備の運転状況を見ると，日平均外気温が一定の 温度以下になってから初めて暖房を行う場合が多い。したがって住 宅の熱設計を行う場合，日平均外気温に基づく暖房開始日を決め， それに基づいてディグリーデーを計算するのが普通である。冷房デ イグリーデーの計算も同じである。毎年の日平均外気温の変動が必
* 筑波技術短期大学建築工学科 助教授. 工博

*** 筑波技術短期大学建築工学科教授・工修

*** 九州大学大学院総合理工学研究科環境工ネルギ一工学尃攻 教授・工博
Assoc. Prof, Dept. of Architectural Eng., Tsukuba College of Tech., Dr. Eng. Prof., Dept. of Architectural Eng., Tsukuba College of Tech., M. Eng.

Prof., Department of Energy and Environmental Engineering, Kyushu University, Dr. Eng. 
表1 各地の暖房ディグリーデーと冷房ディグリーアワー

\begin{tabular}{|c|c|c|c|c|c|c|c|c|c|c|c|c|c|}
\hline \multirow[b]{2}{*}{ 都市 } & \multirow[b]{2}{*}{ 稦度,経度 } & \multicolumn{3}{|c|}{ (㖟房開始温度 $5^{\circ} \mathrm{C}$,室温 $\left.18^{\circ} \mathrm{C}\right)$} & \multicolumn{3}{|c|}{ (瞹房開始温度 $10^{\circ} \mathrm{C}$,至温 $\left.18^{\circ} \mathrm{C}\right)$} & \multicolumn{3}{|c|}{ 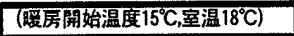 } & \multicolumn{3}{|c|}{ 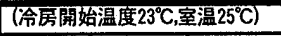 } \\
\hline & & 開始日 & 終了日 & HDD 18(5) & 閔始日 & \begin{tabular}{|l|} 
終了日 \\
\end{tabular} & HDD18(10) & 開始日 & \begin{tabular}{|l|} 
船了日 \\
\end{tabular} & HDD18(15 & 開始日 & \begin{tabular}{|l|l} 
終了日 \\
\end{tabular} & CDH25(23) \\
\hline 北京 & $39^{\circ} 56^{\prime} \mathrm{N}, 116^{\circ} 17^{\prime} \mathrm{E}$ & 11月14日 & 3月9日 & 2112 & 10月29日 & 3月28日 & 2479 & 10月12日 & 4月18日 & 2665 & 5月28日 & 9月3日 & 4184 \\
\hline 長春 & $43^{3} 54^{\prime} \mathrm{N}, 125^{\circ} 13^{\prime} \mathrm{E}$ & 10月22日 & 4月4日 & 4132 & 10月11日 & 4月24日 & 4453 & 9月16日 & 5月16日 & 4683 & 7月20日 & 8月7日 & 365 \\
\hline 長沙 & $28^{\circ} 14^{\prime} \mathrm{N}, 112^{\circ} 52^{\prime} \mathrm{E}$ & 1月6日 & 1月26日 & 281 & 11月27日 & 3月7日 & 1491 & 11月7日 & 4月7日 & 1520 & 5月21日 & 9月14日 & 7724 \\
\hline 成都 & $30^{\circ} 40^{\prime} \mathrm{N}, 104^{\circ} 01^{\prime} \mathrm{E}$ & - & $=$ & 0 & 11月26日 & 3月7日 & 1122 & 10月29日 & 4月7日 & 1441 & 5月29日 & 9月7日 & 2786 \\
\hline 大連 & $38^{8} 54^{\prime} \mathrm{N}, 121^{\circ} 38^{\prime} \mathrm{E}$ & 11月16日 & 3月25日 & 2402 & 11月5日 & 4月12日 & 2695 & 10月12日 & 5月13日 & 2997 & 7月10日 & 9月1日 & 704 \\
\hline 丹東 & $40^{\circ} 03^{\prime} \mathrm{N}, 124^{\prime} 20^{\prime} \mathrm{E}$ & 11月9日 & 3月30日 & 2949 & 10月18日 & 4月21日 & 3366 & 9月26日 & 5月15日 & 3628 & 7月24日 & 8月21日 & 500 \\
\hline 定海 & $30^{\circ} 02^{\prime} \mathrm{N}, 122^{\circ} 07^{\prime} \mathrm{E}$ & - & - & 0 & 12月8日 & 3月29日 & 1206 & 11月9日 & 4月21日 & 1463 & 6月22日 & 9月20日 & 4027 \\
\hline 福州 & $26^{\circ} 05^{\prime} \mathrm{N}, 119^{\circ} 17^{\prime} \mathrm{E}$ & - & - & $\overline{0}$ & - & - & 0 & 11月28日 & 4月3日 & 1008 & 5月23日 & 10月6日 & 8651 \\
\hline 格霜木 & $36^{\circ} 25^{\prime} \mathrm{N}, 94^{\circ} 4^{\prime} \mathrm{E}$ & 10月16日 & 4月6日 & 3670 & 9月26日 & 5月3日 & 4167 & 9月3日 & 6月14日 & 4502 & - & - & 0 \\
\hline 広州 & $23^{\circ} 08^{\prime} \mathrm{N}, 113^{\circ} 19^{\prime} \mathrm{E}$ & - & - & 0 & - & - & 0 & 12月16日 & 3月4日 & 211 & 4月20日 & 10月23日 & 11969 \\
\hline 桂林 & $25^{\circ} 20^{\circ} \mathrm{N}, 110^{\circ} 18^{\prime} \mathrm{E}$ & - & - & 0 & 12月15日 & 3月2日 & 713 & 11月24日 & 4月3日 & 999 & 5月10日 & 10月1日 & 8271 \\
\hline 貴陽 & $26^{3} 35^{\prime} \mathrm{N}, 106^{\circ} 43^{\prime} \mathrm{E}$ & - & - & 0 & 11月25日 & 3月10日 & 1191 & 10月22日 & 4月11日 & 1523 & 6月26日 & 9月2日 & 1368 \\
\hline 哈留 & $42^{\circ} 49^{\prime} \mathrm{N}, 93^{\circ} 31^{\prime} \mathrm{E}$ & 11月2日 & 3月16日 & 2983 & 10月15日 & 3月29日 & 3312 & 9月30日 & \begin{tabular}{|l|} 
4月28日 \\
\end{tabular} & 3507 & 6月1日 & 8月25日 & 5339 \\
\hline 杭州 & $30^{\circ} 14^{\prime} \mathrm{N}, 120^{\circ} 10^{\circ} \mathrm{E}$ & 1月2日 & 2月5日 & 468 & \begin{tabular}{|l|}
11 月26日 \\
\end{tabular} & 3月23日 & 1359 & 11月8日 & 4月16日 & 1582 & 5月31日 & 9月12日 & 6623 \\
\hline 哈尔浜 & $45^{\circ} 45^{\prime} \mathrm{N}, 126^{\circ} 46^{\prime} \mathrm{E}$ & 10月16日 & 4月9日 & 4694 & 10月1日 & \begin{tabular}{|l|}
4 月28日 \\
\end{tabular} & 5016 & 9月12日 & 5月18日 & 5226 & 7月30日 & 8月6日 & 426 \\
\hline 合肥 & $31^{\prime} 52^{\prime} \mathrm{N}, 117^{\circ} 14^{\prime} \mathrm{E}$ & 12月12日 & 2月10日 & 875 & 11月19日 & \begin{tabular}{|l|} 
3月29日 \\
\end{tabular} & 1662 & 10月27日 & \begin{tabular}{|l|} 
4月15日 \\
\end{tabular} & 1854 & 5月31日 & 9月11日 & 5551 \\
\hline 呼和浩特 & $40^{\circ} 49^{\prime} \mathrm{N}, 111^{\circ} 41^{\prime} \mathrm{E}$ & 10月24日 & 4月1日 & 3672 & 10月10日 & 4月24日 & 4022 & 9月16日 & \begin{tabular}{|l|} 
5月6日 \\
\end{tabular} & 4258 & 7月16日 & 7月21日 & 159 \\
\hline 湇南 & $36^{\circ} 41^{\prime} \mathrm{N}, 116^{\circ} 59^{\prime} \mathrm{E}$ & 11月25日 & 3月4日 & 1623 & 11月8日 & 3月28日 & 2032 & 10月16日 & 4月7日 & 2202 & 5月26日 & 9月9日 & 6135 \\
\hline 暴德鎮 & $29^{\circ} 18^{\prime} \mathrm{N}, 117^{\circ} 12^{\prime} \mathrm{E}$ & - & - & 0 & \begin{tabular}{|l|}
11 月27日 \\
\end{tabular} & 3月8日 & 1115 & 11月8日 & 4月7日 & 1391 & 5月21日 & 9月25日 & 8480 \\
\hline 鹐西 & $45^{\circ} 17^{\prime} \mathrm{N}, 130^{\circ} 57^{\prime} \mathrm{E}$ & 10月17日 & 4月10日 & 4532 & 10月2日 & 5月3日 & 4908 & 9月11日 & 5月22日 & 5119 & - & - & 0 \\
\hline 毠什 & $39^{\circ} 28^{\prime} \mathrm{N}, 75^{\circ} 59^{\prime} \mathrm{E}$ & 11月8日 & 3月9日 & 2356 & 10月19日 & 3月27日 & 2753 & 10月3日 & 4月14日 & 2942 & 6月18日 & 8月24日 & 3226 \\
\hline 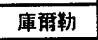 & $41^{\circ} 45^{\prime} \mathrm{N}, 86^{\circ} 08^{\prime} \mathrm{E}$ & 11月5日 & \begin{tabular}{|l|} 
3月10日 \\
\end{tabular} & 2539 & 10月20日 & 3月26日 & 2870 & 10月8日 & 4月14日 & 3036 & 5月29日 & 6月8日 & 346 \\
\hline 星明 & $25^{\circ} 01^{\prime} \mathrm{N}, 102^{\circ} 41^{\prime} \mathrm{E}$ & - & - & 0 & \begin{tabular}{|l|}
11 月27日 \\
\end{tabular} & 2月11日 & 725 & 10月18日 & 3月24日 & 1770 & - & - & 0 \\
\hline 蘭州 & $36^{\circ} 03^{\prime} \mathrm{N}, 103^{\circ} 53^{\prime} \mathrm{E}$ & 11月5日 & 3月11日 & 2716 & \begin{tabular}{|l|}
10 月16日日 \\
\end{tabular} & 4月5日 & 2934 & 9月24日 & 5月15日 & 3186 & 7月17日 & 7月21日 & 249 \\
\hline ラサ & $29^{\circ} 40^{\prime} \mathrm{N}, 91^{\circ} 08^{\prime} \mathrm{E}$ & 11月2日 & \begin{tabular}{|l|} 
3月15日 \\
\end{tabular} & 2277 & 10月15日 & 5月2日 & 2968 & 8月15日 & 5月30日 & 3417 & - & - & 0 \\
\hline 龍州 & $22^{\circ} 22^{\prime} \mathrm{N}, 106^{\circ} 45^{\prime} \mathrm{E}$ & - & - & 0 & $=$ & - & 0 & 12月20日 & 3月1日 & 202 & 4月16日 & 10月20日 & 12148 \\
\hline 南昌 & $28^{\circ} 36^{\prime} \mathrm{N}, 115^{\circ} 55^{\prime} \mathrm{E}$ & - & - & 0 & 11月29日 & 3月9日 & 1099 & 11月8日 & 4月7日 & 1385 & 5月19日 & 9月26日 & 8859 \\
\hline 南京 & $32^{\circ} 00^{\prime} \mathrm{N}, 118^{\circ} 48^{\prime} \mathrm{E}$ & 12月11日 & 2月26日 & 1097 & 11月17日 & 3月29日 & 1676 & 10月26日 & 4月17日 & 1868 & 5月31日 & 9月13日 & 5741 \\
\hline 南事 & $22^{\circ} 49^{\prime} \mathrm{N}, 108^{2} 21^{\prime} \mathrm{E}$ & - & - & 0 & - & - & 0 & 12月17日 & 3月4日 & 332 & 4月18日 & 10月20日 & 12242 \\
\hline 青島 & $36^{\circ} 04^{\prime} \mathrm{N}, 120^{\circ} 20^{\prime} \mathrm{E}$ & 11月27日 & 3月19日 & 1834 & 11月10日 & 4月11日 & 2249 & 10月17日 & 5月7日 & 2506 & 7月7日 & 9月8日 & 1077 \\
\hline 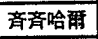 & $47^{\circ} 23^{\prime} \mathrm{N}, 123^{\circ} 55^{\prime} \mathrm{E}$ & 10月16日 & 4月10日 & 4763 & 9月26日 & 5月1日 & 5167 & 9月12日 & 5月16日 & 5325 & - & $=$ & 0 \\
\hline 上海 & $31^{\circ} 1^{\prime} \mathrm{N}, 121^{\circ} 26^{\prime} \mathrm{E}$ & 1月3日 & 2月15日 & 577 & 11月26日 & 3月30日 & 1462 & 11月7日 & 4月21日 & 1674 & 6月8日 & 9月16日 & 5554 \\
\hline 韶関 & $24^{\circ} 48^{\prime} \mathrm{N}, 113^{\circ} 35^{\prime} \mathrm{E}$ & - & - & 0 & - & - & 0 & 11月26日 & 3月30日 & 685 & 5月6日 & 10月16日 & 11668 \\
\hline 㴕閩 & $41^{\circ} 46^{\prime} \mathrm{N}, 123^{\circ} 26^{\prime} \mathrm{E}$ & 11月6日 & 3月28日 & 3251 & 10月15日 & 4月14日 & 3664 & 9月24日 & 5月2日 & 3879 & 6月23日 & 8月27日 & 1622 \\
\hline 唐山 & $39^{\circ} 40^{\prime} \mathrm{N}, 118^{\circ} 09^{\prime} \mathrm{E}$ & 11月10日 & 3月22日 & 2582 & 10月26日 & 4月2日 & 2850 & 10月10日 & 4月28日 & 3071 & 6月15日 & 8月31日 & 2519 \\
\hline 天津 & $39^{\circ} 06^{\prime} \mathrm{N}, 1177^{\circ} 10^{\circ} \mathrm{E}$ & \begin{tabular}{|l|}
11 月15日 \\
\end{tabular} & 3月10日 & 2109 & \begin{tabular}{|l|}
11 月4日 \\
\end{tabular} & 3月31日 & 2476 & 10月17日 & 4月17日 & 2688 & 5月30日 & 9月6日 & 4127 \\
\hline 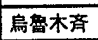 & $43^{\circ} 47^{\prime} \mathrm{N}, 87^{\circ} 37^{\prime} \mathrm{E}$ & 10月25日 & \begin{tabular}{|l|} 
3月29日 \\
\end{tabular} & 3841 & 10月7日 & 4月14日 & 4203 & 9月21日 & 5月12日 & 4428 & 6月26日 & 8月18日 & 1880 \\
\hline 武漠 & $30^{\circ} 37^{\prime} \mathrm{N}, 114^{\circ} 0^{\prime} \mathrm{E}$ & 12月23日 & 2月5日 & 611 & 11月23日 & 3月11日 & 1314 & 11月5日 & 4月7日 & 1609 & 5月20日 & \begin{tabular}{|l|} 
9月14日 \\
\end{tabular} & 7275 \\
\hline 西要 & $34^{\circ} 18^{\prime} \mathrm{N}, 108^{\circ} 56^{\prime} \mathrm{E}$ & 11月23日 & 3月3日 & 1638 & 11月5日 & 3月29日 & 2097 & 10月12日 & 4月16日 & 2328 & 6月3日 & 8月31日 & 4169 \\
\hline 西覃 & $36^{\circ} 37^{\circ} \mathrm{N}, 101^{\circ} 46^{\prime} \mathrm{E}$ & 10月27日 & 3月31日 & 3142 & 10月1日 & 4月26日 & 3671 & 9月3日 & 6月8日 & 4072 & - & - & 0 \\
\hline 崖県 & $18^{\circ} 14^{\prime} \mathrm{N}, 109^{\circ} 31^{\prime} \mathrm{E}$ & - & - & $\overline{0}$ & - & - & 0 & - & - & 0 & 2月14日 & 11月28日 & 17245 \\
\hline 宜昌 & $30^{\circ} 42^{\prime} \mathrm{N}, 111^{\circ} 18^{\prime} \mathrm{E}$ & 1月10日 & 1月24日 & 172 & 11月26日 & 3月10日 & 1188 & \begin{tabular}{|l|}
$11 月 6 日$ \\
\end{tabular} & 4月5日 & 1474 & 5月22日 & 9月11日 & 5813 \\
\hline 伊帣 & $47^{7} 43^{\prime} \mathrm{N}, 128^{\circ} 54^{\prime} \mathrm{E}$ & 10月12日 & 4月14日 & 5380 & 9月22日 & 5月5日 & 5827 & 9月8日 & 5月29日 & 6053 & $\overline{-}$ & - & 0 \\
\hline 银川 & $38^{\circ} 29^{\circ} \mathrm{N}, 106^{\circ} 13^{\prime} \mathrm{E}$ & 11月4日 & 3月26日 & 2953 & 10月14日 & 4月13日 & 3350 & 9月24日 & 5月4日 & 3564 & 7月11日 & 8月11日 & 840 \\
\hline 伊害 & $43^{\circ} 57^{\prime} \mathrm{N}, 81^{\circ} 20^{\circ} \mathrm{E}$ & 11月3日 & 3月22日 & 2998 & 10月10日 & 4月9日 & 3423 & 9月27日 & 4月27日 & 3575 & 6月28日 & 8月6日 & 1393 \\
\hline 部州 & $34^{4} 43^{\prime} \mathrm{N}, 113^{\circ} 39^{\prime} \mathrm{E}$ & 11月26日 & 3月2日 & 1548 & 11月8日 & 3月29日 & 2013 & 10月14日 & 4月14日 & 2217 & 5月30日 & 9月5日 & 4936 \\
\hline
\end{tabular}

ずしも単調でないため, 各地の暖(冷)房開始日は次のように決めてい る。まず，対象都市における各年の日別平均外気温を求め，その日 の平均気温を中心とした 5 日間の単純移動平均を行い, さらに 1982 〜1997 年の間の日別平均気温を求めて, 単調な日平均気温力ーブを 得た。単純移動平均の日数を 5 日間にしたのは 3 日間移動平均で単 調な日平均気温カーブを得ることができなかったためである。この ようにして得た 46 都市における $5^{\circ} \mathrm{C}, 10^{\circ} \mathrm{C}, 15^{\circ} \mathrm{C}$ 開始温度とした 暖房ディグリーデーおよび $23^{\circ} \mathrm{C}$ を開始温度とした冷房ディグリー アワーを表 1 に示す。
3. 標準日気象データ

3-1 標準日気象データの必要性

観測気象デー夕に基づいて作成した 1 時間間隔気象データは日本 の標準気象デー夕 5)や拡張アメダスデータ ${ }^{6)}$ などをはじめ, 数多く 存在している。著者らは中国の 46 都市における標準年気象データを 作成し，それを用いて中国の暖冷房負荷の地域特性を解明している。 このような標準年気象デー夕は住宅の熱挙動のシミュレーションを 行う際大変有意義であるが, デー夕は膨大であるうえ, それを用い て負荷計算を行う際, 標準月における各気象要素の累年平均值から の乘離によって, 標準年気象データで得られる空調負荷は必ずしも 


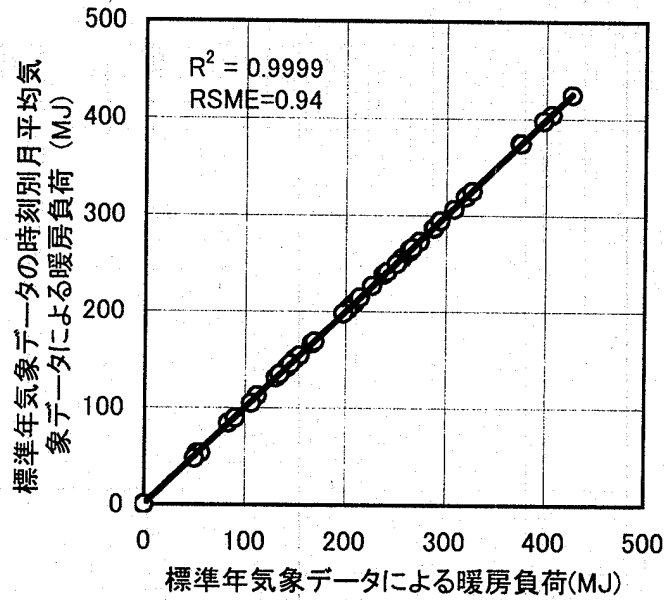

図1 1月における標準年気象デ一タと時刻別月 平均気象データによる暖房負荷の関係

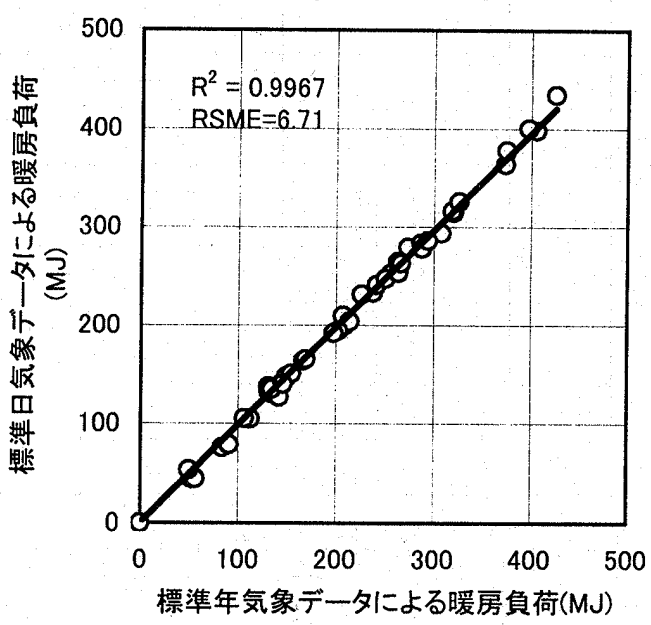

図31月における標準年気象データと標準日気 象データによる暖房負荷の相関

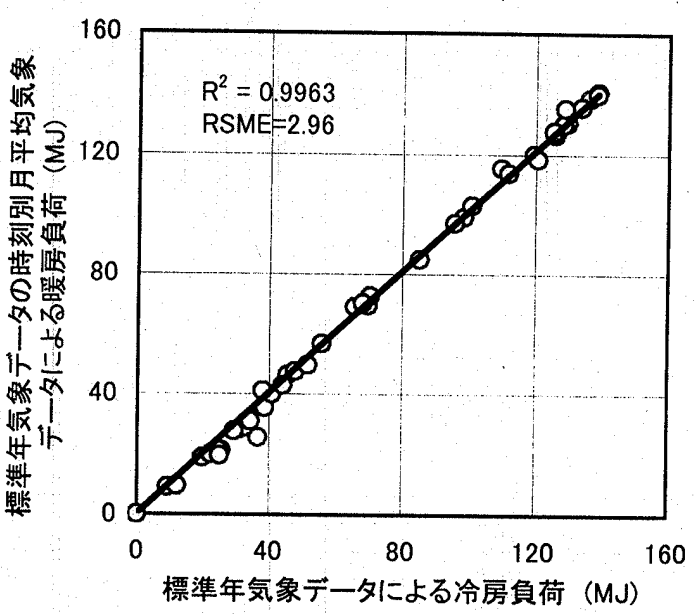

図2 7月における標準年気象データと時刻別月平 均気像デー外による冷房負荷の関係

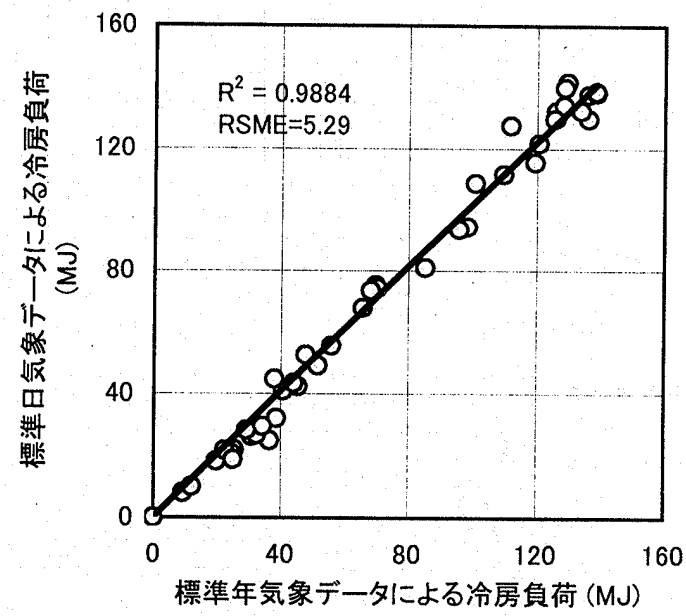

図4７月における標準年気象デ一タと標準日気象 データによる冷房負荷の関係
その累年平均值と一致するとは限らない。さらに，デー夕処理をせ ずに，標準月をべースにした年間気象データからその地方の気候特 性を知ることは難しい。以上の理由で，簡素で，かつその地方の気 候特性を反映した気象データが望まれる。標準日気象データとして 各月の観測気象デー夕の中から空調負荷的に見てもっとも平均的な 日を選ぶことも考えられるが, それを用いて空調負荷計算を行う際, 周期定常になるまで同じ日のデー夕を繰り返して利用するため，1 時の各気象要素のデータが 24 時のそれに近いことが求められる。し かし，観測デー夕を用いる場合，ほとんどの日において，これらの 条件を満たすことは困難である。

時刻別の各気象要素の月平均值を求めれば，それによる空調負荷 がその月の 1 時間間隔の気象デー夕による空調負荷に近いだろうと 推測される。そこで，この仮説を証明するために，以下のシミュレ ーションを行った。まず，シミュレーション用住宅モデルとして前 報に示すモデル $\mathrm{B}^{2)}$ を用いる。このモデルは延床面積が $86.8 \mathrm{~m}^{2}$ とな つており，中国都市部の新築集合住宅の平均的なものである 7)。住 宅はレンガ造とし, 外壁の厚さは一律 $36 \mathrm{~cm}$ である。また, 内壁の 厚さを $24 \mathrm{~cm}$ とする。中国の実際の住宅構造や，レンガの保温性を 考え, 外壁に断熱材を設けないことにする。住宅の換気回数はすべ
て 0.5 回/ $\mathrm{h}$ と仮定し, 空は建物の所在地と関係なく 2 重ガラスとし ている。このような仮定に基づいて算出した熱損失係数 ${ }^{8)}$ は $1.13 W /$ $\mathrm{m}^{20} \mathrm{C}$ とっている。シミュレーションの対象となる住戸は集合住宅 の中間階にあり，同じ階の両端でない住戸を想定している。

次に，表 1 に示す 46 都市における標準年気象デー夕から時刻別 の各気象要素の月平均值を求め, 24 時間分の気象デー夕を得た。そ れを繰り返し，前述した住宅の 1 時間間隔の空調負荷のシミュレー ションを行った。その際，各時刻の空調負荷が日周期の周期定常状 態に入ったことを確認して計算を終了し，1 日分の空調負荷に日数 を乗じて得た負荷值をその月の積算負荷とした。このようにして求 められた 1 月の暖房負荷と 7 月の冷房負荷を前報で述べた標準年気 象デー夕による暖冷房負荷と比較し，それぞれ図 1 と図 2 に示す。 標準年気象データから得られた時刻別の各気象要素の月平均值によ る暖房負荷と冷房負荷は標準年気象データによるそれとの相関が 1 に近く, 空調負荷の月積算値を求める場合, 標準年気象デー夕の時 刻別における各気象要素の月平均值の重複使用で標準年気象データ を代替できることが明らかである。

さらに，解析期間(1982 1997 年)における時刻別の各気象要素月 平均值を求めて各月につき 24 時間分のデー夕を得, それを重複使用 
表2 中国主要都市における標準日気象データ（1月）

\begin{tabular}{|c|c|c|c|c|c|c|c|c|c|c|c|c|}
\hline & & & & & & & & & & & & \\
\hline & 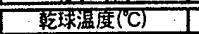 & -5.01 & -5.3 & -5.8 & -5.9 & -6.4 & -6.5 & -6.5 & -6.6 & -5.5 & $-3.81-$ & $-1.95=$ \\
\hline & 绝対湿度 $\left(* 0.1 \mathrm{~g} / \mathrm{kg}^{\prime}\right)$ & 12 & 12 & 12 & 12 & 11 & \begin{tabular}{|c|c|}
12 & -1 \\
\end{tabular} & 12 & 11 & 11 & 11 & 11 \\
\hline 北京 加 & 水平面目射 $\left(\mathrm{W} / \mathrm{m}^{3}\right)$ & 0 & 0 & 0 & 0 & 0 & of & 0 & 35 & 145 & 265 & 369 \\
\hline & 風速 $(\mathrm{m} / \mathrm{s})$ & 2.01 & 1.9 & 2.0 & 2.01 & 2.0 & 2.1 & 2.1 & 2.1 & 2.4 & 2.6 & 2.9 \\
\hline & 雲弯 & & 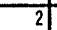 & 2 & $\overline{2}$ & 2 & 3 & 3 & o & 3 & 3 & 0 \\
\hline & 乾球温度('C) & -16.3 & -16.5 & $-17.1-$ & $-177,4$ & -17.7 & -18.0 & -17.9 & -18.0 & -16.8 & \begin{tabular}{l|l}
-15.1 & -1 \\
\end{tabular} & 13.2 \\
\hline & 絶刘湿度( $\left(* 0.1 \mathrm{~g} / \mathrm{kg}^{\prime}\right)$ & 81 & 7 & 8 & 8 & 7 & 7 & & 7 & 8 & 8 & \\
\hline 長春 & 水平面日射量 $\left(\mathrm{W} / \mathrm{m}^{\prime}\right)$ & 0 & 0 & 0 & of & 0 & 0 & 0 & 58 & 146 & \begin{tabular}{l|l}
235 & 3 \\
\end{tabular} & 309 \\
\hline & 風速 $(\mathrm{m} / \mathrm{s})$ & 2.9 & 2.9 & 2.9 & 2.9 & 2.9 & 3.0 & 3.0 & 3.0 & 3.5 & 4.0 & 4.5 \\
\hline & 筑部 & 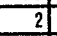 & 2 & 2 & 2 & 2 & 2 & 2 & 2 & - & 2 & 2 \\
\hline & 乾球温度 $\left({ }^{\circ} \mathrm{C}\right)$ & 4.0 & 3.8 & 3.5 & 3.4 & 3.3 & 3.1 & 3.1 & 3.1 & 3.6 & 4.4 & 5.2 \\
\hline & 絶対湿度( $\left(* 0.1 \mathrm{~g} / \mathrm{kg}^{\prime}\right)$ & 45 & 44 & 44 & 44 & 43 & 44 & 43 & 43 & 44 & 44 & 44 \\
\hline 長沙 & 永平面日射 $\left(\mathrm{W} / \mathrm{m}^{2}\right)$ & of & 0 & 0 & $n$ & 0 & 0 & & 30 & 92 & 158 & 221 \\
\hline & 国速 $(\mathrm{m} / \mathrm{s})$ & 1.9 & 1.9 & 1.9 & 1.9 & 1.9 & 2.0 & 2.0 & 2.1 & 2.2 & 2.4 & 2.6 \\
\hline & 雲量 & & & 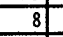 & 4 & & 8 & 70 & 8 & 8 & 8 & 8 \\
\hline & 乾球温度 $\left({ }^{\circ} \mathrm{C}\right)$ & 4.4 & 4.2 & 3.9 & 3.8 & 3.6 & 3.4 & 3.3 & 3.2 & 3.5 & 4.3 & 5.3 \\
\hline & 絶对湿度 $(* 0.1 \mathrm{~g} / \mathrm{kg})$ & 47 & 46 & 47 & 46 & 45 & 46 & 45 & 44 & 46 & 47 & 47 \\
\hline 成都 & 水平面白射害 $\left(\mathrm{W} / \mathrm{m}^{3}\right)$ & & of & 0 & 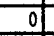 & 0 & 0 & 0 & 0 & 40 & 98 & 163 \\
\hline Dx alp & 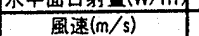 & 0.6 & 0.5 & 0.6 & 0.6 & 0.6 & 0.6 & 0.5 & 0.5 & 0.6 & 0.8 & 0.9 \\
\hline & 雲曋 & 4 & 8 & $\frac{8}{8}$ & & 8 & 0 & 8 & 8 & 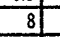 & 9 & 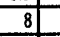 \\
\hline & 乾球温度 $\left({ }^{\circ} \mathrm{C}\right)$ & 9.6 & 9.5 & 9.2 & 9.2 & 9.0 & 8.9 & 9.0 & 9.0 & 9.7 & 10.7 & \begin{tabular}{l|l}
11.8 & 1 \\
\end{tabular} \\
\hline & 絶対湿度 (*0.18//kg') & 61 & 60 & 60 & 60 & \begin{tabular}{l|l}
59 \\
\end{tabular} & 60 & 60 & 59 & 60 & 60 & 60 \\
\hline 福州 & 水平面日射量 $\left(\mathrm{W} / \mathrm{m}^{2}\right)$ & 4 & 0 & 0 & 0 & 0 & 0 & 5 & 67 & 144 & 225 & 304 \\
\hline & 国速 $(\mathrm{m} / \mathrm{s})$ & 2.2 & 2.1 & 2.1 & 2.1 & 2.0 & 1.9 & 1.8 & 1.7 & 1.8 & 1.9 & 2.0 \\
\hline & 害量 & 8 & 8 & 8 & 8 & 8 & 8 & 8 & 8 & $\because$ & 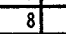 & 7 \\
\hline & 乾球温度 $\left({ }^{\circ} \mathrm{C}\right)$ & 12.3 & \begin{tabular}{|l|}
12.1 \\
\end{tabular} & 11.7 & 11.6 & 11.4 & 11.2 & 11.3 & 11.3 & 12.2 & 13.6 & \begin{tabular}{l|l}
14.9 & 1 \\
\end{tabular} \\
\hline & 絶対湿度 (*0.18/ $\left./ \mathrm{kg}^{\prime}\right)$ & 71 & 70 & 70 & 69 & 67 & 68 & 68 & 67 & 67 & 67 & 66 \\
\hline 公州 & 水平面日射 & 0 & 0 & 0 & 0 & 0 & 0 & of & 54 & 148 & 257 & 364 \\
\hline & 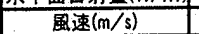 & 2.9 & 3.2 & 2.9 & 2.6 & 2.3 & 2.0 & 1.6 & 1.3 & 1.5 & 1.8 & 2.1 \\
\hline & 雲量 & 6 & 6) & 7 & 7 & 7 & 7 & 7 & 7 & 7 & & 6 \\
\hline & 乾球温 & -20.6 & -20.9 & -21.3 & -21.3 & -21.5 & -21.8 & -21.5 & -21.5 & -20.2 & -18.2 & $\begin{array}{l}5.9-1 \\
15.9\end{array}$ \\
\hline & 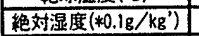 & 6 & 5 & 6 & $\frac{6}{6}$ & 5 & 6 & 6 & $\because$ & 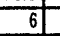 & & \\
\hline 哈尔浜 & 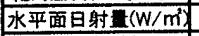 & & of & 0 & of & 0 & 0 & 0 & 55 & 136 & 216 & 278 \\
\hline & 風速 $(\mathrm{m} / \mathrm{s})$. & 2.2 & 2.2 & 2.7 & 3.2 & 3.6 & 3.5 & \begin{tabular}{l|l}
3.3 \\
\end{tabular} & 3.2 & 3.2 & 3.3 & 3.3 \\
\hline & 雲重 & 2 & & $\frac{3}{3}$ & & & $\ldots$ & 3 & & 3 & 3 & 3 \\
\hline & 䡎球温度 $\left({ }^{\circ} \mathrm{C}\right)$ & -13.0 & -13.4 & -14.0 & -14.2 & -14.5 & -15.0 & -15.1 & -15.3 & -14.0 & -11.9 & -9.7 \\
\hline & 絶対湿度 $\left(* 0.1 \mathrm{~g} / \mathrm{kg}^{\prime}\right)$ & 9 & 8 & 9 & 9 & 8 & 8 & 8 & 8 & $\pi$ & 10 & 10 \\
\hline 浩 & 水平面白射量 $(\mathrm{W} / \mathrm{m}$ & 0 & 0 & 0 & 0 & 0 & 0 & 0 & & 93 & 200 & 302 \\
\hline & 風速 $(\mathrm{m} / \mathrm{s})$ & 1.1 & 1.0 & 1.0 & 1.0 & 0.9 & 0.8 & 0.8 & 0.7 & 0.9 & 1.2 & 1.4 \\
\hline & 雲量 & 2 & & 2 & 2 & 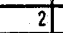 & 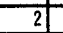 & 2 & & 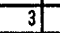 & $\overline{3}$ & $\overline{3}$ \\
\hline & 乾球温度( $\left.{ }^{\circ} \mathrm{C}\right)$ & \begin{tabular}{|c|}
-3.3 \\
\end{tabular} & \begin{tabular}{|l|}
-4.0 \\
\end{tabular} & -4.8 & -5.5 & -6.1 & -6.7 & -7.1 & -7.5 & -6.7 & -5.2 & -3.2 \\
\hline & 䎦対湿度 (*0.1g/kg') & 9 & \begin{tabular}{|l|}
9 \\
\end{tabular} & 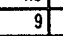 & g) & $\frac{8}{8}$ & 9 & 9 & 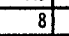 & 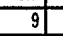 & 9 & 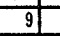 \\
\hline ラサ & 水平面日射 $\left(\mathrm{W} / \mathrm{m}^{2}\right)$ & 0 & 0 & 0 & 0 & 0 & 0 & 0 & 0 & $\pi$ & 159 & 328 \\
\hline & 風速( $(\mathrm{m} / \mathrm{s})$ & 3.0 & 2.7 & 2.5 & 2.3 & 2.0 & 2.0 & 2.0 & 1.9 & 2.1 & 2.4 & 2.6 \\
\hline & $\frac{1}{5}$ & & 2 & 2 & 2 & 2 & $\frac{2}{2}$ & $\frac{2}{2}$ & $\frac{2}{2}$ & 4 & 4 & $\frac{1}{2}$ \\
\hline & 乾球温目 & 1.0 & 0.8 & 0.4 & 0.3 & \begin{tabular}{l|l}
0.1 & \\
\end{tabular} & -0.1 & 0.11 & 0.1 & 1.2 & 2.6 & 4.1 \\
\hline & 䋓対湿度( $(+0)$ & 35 & 34 & 34 & 34 & 33 & 34 & 34 & 33 & 34 & 35 & 34 \\
\hline 南京 & 水平面日射量 $(\mathrm{W} / \mathrm{m})$ & 0 & 0 & 0 & of & 0 & 0 & 0 & 54 & 142 & 241 & 332 \\
\hline & 風速( $\mathrm{m} / \mathrm{s})$ & 1.9 & 1.8 & 1.8 & 1.8 & 1.7 & 1.7 & 1.7 & 1.6 & 2.0 & 2.4 & 2.8 \\
\hline & 雲量 & 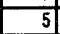 & 5 & 5 & $\pi$ & 5 & 5 & 6 & 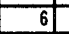 & $\ldots$ & $\pi$ & 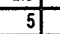 \\
\hline & 乾球温度 $\left({ }^{\circ} \mathrm{C}\right)$ & 3.0 & 2.8 & 2.5 & 2.59 & 2.4 & 2.2 & 2.5 & 2.6 & 3.5 & 4.7 & 5.9 \\
\hline & 绝对湿度 & 39 & 38 & 39 & 39 & 38 & 38 & 38 & 38 & 39 & 39 & 38 \\
\hline 上海 & 水平面日射 $(\mathrm{W} / \mathrm{m})$ & & & $\because$ & 0 & 0 & 0 & - & 78 & 172 & 269 & 346 \\
\hline & 蛆速 $(\mathrm{m} / \mathrm{s}$ & 2.2 & 2.2 & 2.2 & 2.2 & 2.3 & 2.3 & 2.3 & 2.3 & 2.7 & 3.0 & 3.3 \\
\hline & 雲䨌 & & & & 5 & & & & 5 & & & \\
\hline & 乾球温度 $\left({ }^{(} \mathrm{C}\right)$ & \begin{tabular}{|r|}
-13.1 \\
\end{tabular} & -13.5 & -14.0 & -14.1 & -14.4 & -14.7 & -14.6 & -14.7 & -13.3 & -11.2 & -9.1 \\
\hline & 䋓对湿度(* & 10 & 9 & 9 & 9) & 9 & 9 & g) & 9 & 10 & 10 & 10 \\
\hline 潘陽 & 水平面日射量( $\left(\mathrm{W} / \mathrm{m}^{2}\right.$ & 0 & 0 & & 0 & 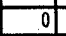 & & & 56 & 149 & 251 & 343 \\
\hline & 風速 $(\mathrm{m}$ & 2.2 & 2.2 & 2.2 & 2.2 & 2.1 & 2.1. & 2.2 & 2.2 & 2.4 & 2.5 & 2.7 \\
\hline & 艝 & & & 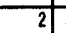 & 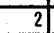 & 1 & 1 & 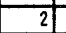 & $=$ & 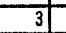 & 3 & 2 \\
\hline & 䡎球温度(10 & -5.0 & -5.0 & -5.4 & -5.5 & -5.7 & -6.1 & \begin{tabular}{|l|}
-5.9 \\
\end{tabular} & -6.0 & -4.9 & -3.3 & -1.6 \\
\hline & 绝対湿度 (*0. & 16 & 16 & $\frac{16}{16}$ & $\frac{16}{16}$ & 15 & 16 & 16 & 15 & $\frac{16}{16}$ & 16 & $\frac{16}{16}$ \\
\hline 天津 & 水平面日 & & & & 7 & $\pi$ & - & 0 & 39 & 139 & 247 & 340 \\
\hline & 風速 $(\mathrm{m} / \mathrm{s})$ & 1.5 & 1.5 & 1.6 & 1.6 & 1.6 & 1.6 & 1.7 & 1.7 & 2.0 & 2.3 & 2.7 \\
\hline & 雲 & & & & 2 & & -1 & $\frac{3}{3}$ & $\cdots$ & & 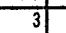 & \\
\hline & 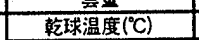 & -12.8 & $\mid-12.9$ & -13.3 & -13.3 & -13.5 & -13.8 & -13.6 & -13.7 & -13.4 & -12.8 & -11.9 \\
\hline & 绝対湿度 $\left(* 0.1 \mathrm{~g} / \mathrm{kg}^{\prime}\right)$ & 12 & & 12 & 11 & 11 & & 11 & 11 & 11 & 12 & $\pi$ \\
\hline 太 & 水平面目射 $\left(W / m^{\prime}\right)$ & & & 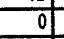 & 0 & 0 & 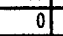 & 0 & $\cdots$ & $\cdots$ & 19 & 87 \\
\hline & 風速 $(\mathrm{m} /$ & 1.4 & 1.3 & 1.3 & 1.3 & 1.2 & 1.3 & 1.3 & $\frac{1.2}{1.2}+x-1$ & $\frac{1.3}{1.3}$ & 1.4 & $\frac{1.4}{1.4}$ \\
\hline & 雲量 & 4 & 3 & & & & & & & 4 & & \\
\hline & 球温度 & 2.7 & 2.5 & 2.1 & 2.0 & 1.8 & 1.5 & 1.6 & 1.6 & 2.4 & 3.5 & 4.8 \\
\hline & 絶対湿度(* & 39 & 38 & 38 & 38 & $\overline{37}$ & $\overline{38}$ & 37 & 37 & & 38 & 38 \\
\hline 式漢 & 水平面目射量 $\left(\mathrm{W} / \mathrm{m}^{3}\right)$ & 0 & 0 & 0 & 0 & 0 & 01 & 0 & 35 & 111 & 196 & 274 \\
\hline & 屋速 $(\mathrm{m}$ & 1.4 & 1.4 & 1.4 & 1.4 & 1.3 & 1.4 & 1.4 & 1.4 & 1.6 & 1.8 & 2.0 \\
\hline & $\frac{\sqrt{4}}{4}$ & & & & & & & & 6 & & & \\
\hline & 新球温度 $\left({ }^{(} \mathrm{C}\right)$ & -1.4 & -1.7 & -2.1 & -2.2 & $|-2.3|$ & $|-2.7|$ & $|-2.7|$ & \begin{tabular}{|l|}
-2.9 \\
\end{tabular} & -2.3 & -1.2 & 0.1 \\
\hline & 絶対湿 & 25 & 25 & 25 & 25 & 24 & 24 & 24 & 23 & 24 & 25 & 24 \\
\hline 西安 & 永平面日 & & & & 0 & & 0 & $\pi$ & & $\overline{81}$ & 167 & 252 \\
\hline & 風速 $(\mathrm{m} / \mathrm{s})$ & 0.8 & 0.8 & 0.9 & 0.9 & 0.9 & 0.9 & 0.9 & 0.9 & 1.0 & 1.2 & 1.4 \\
\hline & 雲 & & & & & & 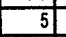 & & & 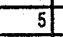 & & 5 \\
\hline & 乾球温度('C) & -1.7 & -1.9 & -2.3 & -2.5 & $\mid-2.7$ & -3.0 & -2.9 & -3.0 & -1.7 & 0.1 & 2.0 \\
\hline & $\frac{1}{\left.\mathrm{~g} / \mathrm{Kg}^{\prime}\right)}$ & 24 & 23 & 23 & 23 & 22 & 23 & 22 & 22 & 22 & 22 & 22 \\
\hline 部州 & 水平面日 & 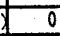 & 0 & $\frac{10}{0}+30$ & 0 & 0 & 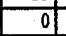 & 0 & 30 & 129 & 247 & 352 \\
\hline & 風速( $(\mathrm{m} / \mathrm{s})$ & 1.9 & 1.9 & 1.9 & 1.8 & $\mid 1.7$ & 1.8 & 1.8 & 1.8 & 2.2 & 2.6 & 2.9 \\
\hline & & & & & & & & 0 & 10 & -5 & 0 & \\
\hline
\end{tabular}


表3 中国主要都市における標準日気象データ(7月)

\begin{tabular}{|c|c|c|c|c|c|c|c|c|c|c|c|c|}
\hline 陑 & 北宗眭间 & & & & & Jurg & 0 时 & & OHF & 箱 & 10日时 & |111日时 \\
\hline & 乾球温度( & 24.0 & 23.7 & 23.2 & 23.0 & 22.7 & 23.0 & 23.9 & 24.5 & 25.4 & 26.5 & 27.4 \\
\hline & 䌊対湿度( $\left(0.1 \mathrm{~g} / \mathrm{kg}^{\prime}\right)$ & 154 & 152 & 152 & 152 & 150 & 151 & 151 & 150 & 151 & 751 & 150 \\
\hline 北京 & 水平面日射 $\left(\mathrm{W} / \mathrm{m}^{\prime}\right)$ & $\square$ & 0 & 0 & 0 & 1 & 53 & 134 & 218 & 324 & 404 & 479 \\
\hline & 国速 $(\mathrm{m} / \mathrm{s})$ & 1.5 & 1.3 & 1.4 & 1.3 & 1.3 & 0.5 & 1.6 & 1.8 & 1.9 & 2.0 & 2.1 \\
\hline & 雲量 & & 4 & 7 & 7 & 77 & 7 & 7 & 7 & $\rightarrow$ & 7 & 7 \\
\hline & 乾球温度 $\left({ }^{\circ} \mathrm{C}\right)$ & 20.4 & 20.2 & 19.8 & 19.8 & 19.6 & 20.1 & 21.4 & 22.3 & 23.3 & 24.1 & 24.8 \\
\hline & 絶対湿度( $\left(* 0.1 \mathrm{~g} / \mathrm{kg}^{\prime}\right)$ & 133 & 131 & 131 & 131 & 129 & 132 & 133 & 135 & 136 & 136 & 136 \\
\hline 長春 & 水平面日射 & 0 & 0 & 0 & 0 & 39 & 1111 & 209 & 307 & 413 & 468 & 508 \\
\hline & 風速 $(\mathrm{m} / \mathrm{s})$ & 2.3 & 2.3 & 2.4 & 2,4 & 2.4 & 2.7 & 3.0 & 3.2 & 3.4 & 3.6 & 3.7 \\
\hline & 需量 & & 5 & & & 6 & & 7 & 7 & & 4 & \\
\hline & 乾球温度 $\left({ }^{\circ} \mathrm{C}\right)$ & 26.9 & 26.6 & 26.3 & 26.2 & 26 & \begin{tabular}{|l|}
26.2 \\
\end{tabular} & 26.9 & 27.3 & 28.3 & 29.4 & \begin{tabular}{|l|}
30.3 \\
\end{tabular} \\
\hline & 绝対湿度 (*0.18/(kg') & 191 & 189 & 189. & 188 & 186 & 187 & 188 & 188 & 189 & 189 & 188 \\
\hline 長沙 & 永平面日射重 $(\mathrm{W} / \mathrm{m})$ & & 0 & 0 & 0 & 0 & 77 & 104 & 196 & 317 & \begin{tabular}{l|l}
423 \\
\end{tabular} & 524 \\
\hline & 風速 $(\mathrm{m} / \mathrm{s})$ & 1.7 & 1.6 & 1.7 & 1.7 & 7.6 & 1.8 & 2.0 & 2.1 & 2.4 & 2.8 & 3.1 \\
\hline & 票基 & 5 & 5 & -1 & 6 & 6 & 6 & 7 & 7 & 7 & 7 & 7 \\
\hline & 乾球温度 $\left.{ }^{\circ} \mathrm{C} C\right)$ & 23.5 & 23.2 & 22.9 & 22.7 & 22.5 & \begin{tabular}{|l|}
22.5 \\
\end{tabular} & 22.9 & \begin{tabular}{|l|}
23.0 \\
\end{tabular} & 23.9 & 24.9 & \begin{tabular}{|l|}
25.9 \\
\end{tabular} \\
\hline & 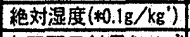 & 171 & 168 & 167 & 166 & 163 & 164 & 165 & 165 & 167 & .168 & 169 \\
\hline 成都 & 水平面时射 $\left(\mathrm{W} / \mathrm{m}^{3}\right)$ & 0 & 0 & 0 & 0 & 0 & of & 35 & 88 & 171 & 263 & 364 \\
\hline & 會速 $(\mathrm{m} / \mathrm{s})$ & 1.0 & 1.0 & 1.0 & 0.9 & 0.9 & 0.9 & 0.9 & 0.9 & 1.1 & 1.3 & 1.5 \\
\hline & 雲支 & & 8 & & 20 & 8 & 8 & 8 & & & & \\
\hline & 乾球温度( $\left({ }^{\circ} \mathrm{C}\right)$ & 26.8 & 26.6 & 26.3 & 26.2 & 26.1 & \begin{tabular}{|l|}
26.3 \\
\end{tabular} & 27.3 & \begin{tabular}{|l|}
27.9 \\
\end{tabular} & 29.0 & 30.3 & \begin{tabular}{|l|}
31.5 \\
\end{tabular} \\
\hline & 绝対湿度 $\left(40.1 \mathrm{~g} / \mathrm{kg}^{\prime}\right)$ & 190 & 189 & 189 & 189 & 187 & \begin{tabular}{|c|}
1899 \\
\end{tabular} & 190 & 191 & 191 & 191 & 190 \\
\hline 福州 & 水平面日射 & 0 & 0 & 0 & 0 & 0 & $46 \mid$ & 145 & 248 & 381 & 493 & 601 \\
\hline & 者速 $(\mathrm{m} / \mathrm{s})$ & 2.4 & 2.0 & 1.9 & 1.7 & 1.5 & 1.5 & 1.5 & 1.4 & 1.8 & 2.2 & 2.6 \\
\hline & 䨌量 & & 5 & 6 & 6 & 7 & & 7 & 7 & 7 & 7 & 6 \\
\hline & 乾球温度( $\left.{ }^{\circ} \mathrm{C}\right)$ & 27.0 & 26.9 & 26.5 & 26.5 & 26.3 & 26.5 & 27.3 & 27.8 & 28.7 & 29.6 & 30.4 \\
\hline & 绝対湿庭 $\left(* 0.1 \mathrm{~g} / \mathrm{kg}^{\prime}\right)$ & 202 & 201 & 201 & 201 & 199 & 200 & 201 & \begin{tabular}{|l|}
201 \\
\end{tabular} & 200 & 199 & 196 \\
\hline 広州 & 水平面日射㗐 $(\mathrm{w} / \mathrm{m})$ & 0.0 & 0.0 & 0.0 & 0.0 & 0.0 & 6 & 97 & 189 & 305 & 390 & 473 \\
\hline & 風速 $(\mathrm{m} / \mathrm{s})$ & 1.3 & 1.1 & 1.1 & 1.0 & 1.0 & 1.2 & 1.5 & 1.7 & 2.0 & 2.2 & 2.4 \\
\hline & 需量 & - & 6 & 6 & 6 & 6 & 7 & 7 & 7 & 8 & 8 & 8 \\
\hline & 乾球温度( & 19.3 & 19.0 & 18.7 & 18.7 & 18.6 & \begin{tabular}{|l|}
19.3 \\
\end{tabular} & 21.0 & \begin{tabular}{|l|}
22.1 \\
\end{tabular} & 23.3 & 24.2 & \begin{tabular}{|l|}
24.8 \\
\end{tabular} \\
\hline & 好湿度 $\left(* 0.1 \mathrm{~g} / \mathrm{kg}^{\prime}\right)$ & 126 & 123 & 124 & 123 & 122 & 125 & 128 & 131 & 132 & 132 & 131 \\
\hline 哈尔浜 & 水平面日射 & & 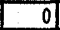 & 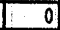 & 0 & 50 & 126 & 237 & 349 & 455 & 497 & 523 \\
\hline & 風速(m/s) & 2.3 & 2.2 & 2.3 & 2.3 & 2.31 & 2.7 & 3.1 & 3.5 & 3.6 & 3.7 & 3.7 \\
\hline & 寨量 & - & 5 & 6 & 6 & 7 & 7 & 7 & 7 & 7 & 7 & 7 \\
\hline & 䡎球温度 $\left({ }^{\circ} \mathrm{C}\right)$ & 19.4 & 18.8 & 18.2 & 17.8 & 17.4 & 17.9 & 19.5 & 20.5 & 21.9 & 23.2 & 24.2 \\
\hline & 絶対湿度 (*0.1g/ $\left./ \mathrm{kg}^{\prime}\right)$ & 97 & 96 & 96 & 95 & 94 & 95 & 96 & 97 & 98 & 98 & 97 \\
\hline 浩物 & 水平面目射 $(\mathrm{W} / \mathrm{m})$ & 0 & 0 & 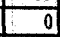 & (1) & 0 & 43 & 125 & 213 & 317 & 394 & 471 \\
\hline & 闽速 $(\mathrm{m} / \mathrm{s})$ & 2.3 & 2.3 & 2.4 & 2.4 & 2.4 & 2.6 & 2.8 & 2.9 & 3.2 & 3.3 & 3.5 \\
\hline & 霹量 & 6 & 6 & & 7 & 7 & 8 & 8 & 81 & 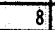 & -1 & \\
\hline & 乾球温裹( & 14.1 & 13.4 & 12.9 & 12.3 & 11.9 & 11.6 & 11.5 & 11,3 & 12.5 & 14.1 & 15.9 \\
\hline & 絶对湿度( $\left(* 0.1 \mathrm{~g} / \mathrm{kg}^{\prime}\right)$ & 65 & 65 & 65 & 65 & 65 & 65 & 65 & 65 & 65 & 65 & 64 \\
\hline ラサ & 水平面日射 $\left.(\mathrm{W} / \mathrm{m})^{2}\right)$ & 0 & 0 & 0 & 0 & of & of & 0 & 53 & 152 & 291 & 474 \\
\hline & 国速( $(\mathrm{m} / \mathrm{s})$ & 1.61 & 1.5 & 1.5 & 1.47 & 1.4 & 1.36 & 1.3 & 1.2 & 1.41 & 1.59 & 1.76 \\
\hline & 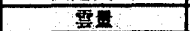 & 70 & 7 & 7 & 8 & 7 & 8 & 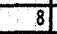 & 8 & 8 & 8 & 7 \\
\hline & 乾球温度 ${ }^{\left({ }^{\circ} \mathrm{C}\right)}$ & 25.9 & 25.7 & 25.4 & 25.3 & 25.2 & 25.5 & 26.5 & 27.1 & 28 & 28.9 & 29.7 \\
\hline & 絶对湿度 $\left(* 0.18 / \mathrm{kg}^{\prime}\right)$ & 191 & 189 & 190 & 189 & 187 & 189 & 101 & 191 & 192 & 192 & 191 \\
\hline 南京 & 水平面日射 $(\mathrm{W} / \mathrm{m}$ & $\overline{0}$ & 0 & $\overline{0}$ & 0 & of & 49 & 137 & 234 & 348 & 433 & 509 \\
\hline & 風速 $(\mathrm{m} / \mathrm{s})$ & 1.6 & 1.5 & 1.5 & 1.5 & 1.5 & 1,8 & 2.1 & 2.4 & 2.8 & 3.2 & \begin{tabular}{c|c|}
3.5 \\
\end{tabular} \\
\hline & 雲部 & 6 & 6 & 6 & 7 & 7 & & 7 & 7 & 7 & 7 & \\
\hline & 乾球温度( & 26.1 & 26 & 25.9 & 25.8 & 25.8 & 26.2 & & 27.8 & 28.7 & 29.5 & 30.2 \\
\hline & 緇对湿度 & 194 & 193 & 193 & 193 & 191 & \begin{tabular}{|c|}
193 \\
\end{tabular} & 194 & 195 & 196 & 196 & \begin{tabular}{|c|}
195 \\
\end{tabular} \\
\hline 上海 & 水平面目射量 $(\mathrm{W} / \mathrm{m}$ & 0 & 0 & 0 & of & 0 & 64 & 159 & 259 & 368 & 437 & 495 \\
\hline & 風速 $(m$ & 2.4 & 2.3 & 2.3 & 2.2 & 2.1 & 2.4 & 2.7 & 3.0 & 3.2 & 3.4 & 3.6 \\
\hline & & & & & & & & & & & & \\
\hline & 䡎球温度 $\left({ }^{\circ} \mathrm{C}\right)$ & 21.7 & 21.3 & 21 & 20.8 & \begin{tabular}{|l|}
20.6 \\
\end{tabular} & \begin{tabular}{|l|}
21.1 \\
\end{tabular} & 22.4 & \begin{tabular}{|l|}
23.22 \\
\end{tabular} & 24.4 & 25.3 & \begin{tabular}{|l|}
26.1 \\
\end{tabular} \\
\hline & 絶刘湿度(* & 142 & 139 & 139 & 138 & 136 & 138 & 141 & 142 & 144 & 145 & 144 \\
\hline 潘陽 & 永平面目 & 0 & & 0 & 0 & 25 & 95 & 192 & 290 & 400 & 464 & 317 \\
\hline & 虫速 $(\mathrm{m} /$ & 2.0 & 1.9 & 1.9 & 1.9 & 1.9 & 2.1 & 2.4 & 2.6 & 2.9 & 3.2 & 3.4 \\
\hline & 寒量 & $=$ & 5 & 6 & 6 & 7 & 7 & 7 & 7 & 7 & 7 & \\
\hline & 速温 & 24.0 & 24.0 & 23.6 & 23.4 & 23.1 & \begin{tabular}{|l|}
23.4 \\
\end{tabular} & 24.4 & 25.0 & 26.1 & 27.1 & \begin{tabular}{|l|}
27.9 \\
\end{tabular} \\
\hline & 絶対湿度 & 158 & 158 & 158 & 157 & 155 & \begin{tabular}{|l|}
157 \\
\end{tabular} & 157 & 157 & 158 & 158 & \begin{tabular}{|l|}
157 \\
\end{tabular} \\
\hline E津 & 水平面日 & & 0 & 0 & & & 61 & 150 & 239 & 354 & 435 & 508 \\
\hline & & 1.5 & 1.5 & 1.4 & 1.4 & 1.3 & & 1.7 & 1. & & 2.2 & 2.3 \\
\hline & 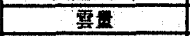 & 5.6 & 5.6 & 5.8 & 6.2 & & 6.3 & 6.6 & 6.5 & 6.7 & 6.9 & 6.6 \\
\hline & 家温 & 21.8 & 20.9 & 20.3 & 19.9 & 19.6 & \begin{tabular}{|l|}
19.3 \\
\end{tabular} & 19.4 & 19.3 & 20.7 & 22.6 & 24.4 \\
\hline & 絶対湿度 & & & & & 75 & & 76 & 75 & & 74 & 71 \\
\hline 木标 & 水平面 & 0 & 0 & 0 & 0 & 0 & 0 & 17 & \begin{tabular}{|l|}
1066 \\
\end{tabular} & 234 & 390 & 555 \\
\hline & 風速 & 2.2 & 2.3 & 2.3 & 2.2 & 2.2 & 2.2 & 2.1 & 2.1 & 2.1 & 2.2 & 2.2 \\
\hline & 需 & & & & & & & & & & & \\
\hline & 乾球温度 ( $(\mathrm{C})$ & 26.7 & 26.5 & 26.2 & 26.1 & 26 & \begin{tabular}{|l|}
26.1 \\
\end{tabular} & 27 & \begin{tabular}{|l|}
27.4 \\
\end{tabular} & 28.3 & 29.1 & \begin{tabular}{|l|}
29.8 \\
\end{tabular} \\
\hline & 䑨対湿度 & 194 & 192 & 192 & 191 & 189 & 190 & 191 & 91 & 301 & 1091 & 190 \\
\hline 武漠 & 水平面白 & & & & & & 271 & 111 & 2071 & 319 & 408 & 488 \\
\hline & 国速 & 1.4 & 1.4 & 1.4 & 1.4 & 1.4 & 1.7 & 2.0 & 2.2 & 2.5 & 2.8 & 3.1 \\
\hline & 雲 & & & & & & & & & & & \\
\hline & 乾球温竡 & 24.8 & 24.7 & 24.1 & 23.5 & 23.0 & 23.0 & \begin{tabular}{|l|}
23.4 \\
\end{tabular} & 23.7 & 24,7 & 26.01 & 27.1 \\
\hline & 湿蔗 & 145 & 144 & 144 & 143 & 142 & 144 & 145 & 145 & 146 & 16 & 147 \\
\hline 西安 & 水平面日 & & & 0 & 0 & & & 80 & $168 \mid$ & 281 & 388 & $489 !$ \\
\hline & 国速 $(\mathrm{m} / \mathrm{s})$ & 1.4 & 1.4 & 1.4 & 1.3 & 1.2 & 1.3 & 1.4 & 1.4 & 1.6 & 1.8 & 1.9 \\
\hline & 雲量 & & & & & & & & & & & \\
\hline & 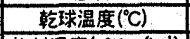 & 24.5 & 2.4 & 23.7 & 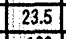 & 23.3 & 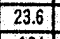 & & 1 & 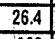 & 27.6 & 0.00 \\
\hline & 绝対湿度( $($ ) & 166 & 164 & 164 & 163 & 161 & \begin{tabular}{|l|}
164 \\
\end{tabular} & 166 & 168 & 169 & 168 & 166 \\
\hline 酠州 & 水平面日射贯 $(\mathrm{W} / \mathrm{m})$ & & 0 & 0 & 0 & 0 & 32 & 114 & 206 & 328 & 420 & 503 \\
\hline & 風速 $(\mathrm{m} / \mathrm{s})$ & 1.7 & 1.6 & 1.6 & 1.5 & 1.4 & 1.5 & 1.6 & 1.7 & 2.0 & 2.3 & 2.6 \\
\hline & & & & & & & & & & & & \\
\hline
\end{tabular}


表4 各地における暖房設計用時刻別温湿度 (冬季)

\begin{tabular}{|c|c|c|c|c|c|c|c|c|c|c|c|c|c|c|c|c|c|c|c|c|c|c|c|c|c|c|c|}
\hline & & & & & & & | 50月寺工 & 6时寺 & & 8時 & 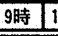 & L & Iयकि 1 & 12時 11 & 13B & 14時 [1 & 15時 1 & 16时 1 & 177時 1 & 18時 & 19時 | 2 & 20時 2 & 2121时 & ZZ时 & 233時 & 2448 & 季設計温度4 \\
\hline \multirow{4}{*}{ 北京 } & & 樹球温度('C) & -9.7 & -10.0 & -10.5 & -10.8 & -11.3 & -11.4 & -11.4 & $-11.7-1$ & -10.4 & -8.4 & \begin{tabular}{l|l|}
-6.9 \\
\end{tabular} & -5.9 & \begin{tabular}{l|l|}
-5.3 \\
\end{tabular} & -5.0 & \begin{tabular}{|c|}
$-5.0 \mid$ \\
\end{tabular} & -5.2 & -5.8 & \begin{tabular}{|l|}
-6.3 \\
\end{tabular} & \begin{tabular}{l|l|}
-6.9 \\
\end{tabular} & -7.6 & -8.2 & -8.6 & -9.11 & - -9.6 & \\
\hline & & 绝対湿度 $\left(\mathrm{g} / \mathrm{kg}^{\prime}\right)$ & 0.3 & 0.2 & 0.3 & 0.3 & 0.3 & 0.3 & 0.3 & 0.2 & \begin{tabular}{l|l}
0.3 \\
\end{tabular} & 0.2 & 0.2 & 0.2 & 0.2 & 0.2 & 0.2 & 0.2 & 0.2 & 0.3 & 0.3 & 0.2 & 0.3 & 0.3 & 0.2 & 0.3 & 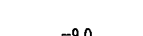 \\
\hline & $5.0 \%$ & 乾球温度 ( & -8.7 & -9.1 & -9.7 & $-9.7-$ & $|-10.1|-$ & -10.4 & $-10.3-$ & -10.4 & -9.1 & -7.6 & -6.1. & -4.9 & \begin{tabular}{|l|}
-4.2 \\
\end{tabular} & -3.9 & -3.7 & -4.2 & -4.6 & -5.0 & -5.7 & $-6: 4$ & -6.9 & -7.4 & -7.9 & -8.5 & 0.0 \\
\hline & & 秝対湿度(g/kg') & 0.4 & 0.3 & 0.4 & 0.4 & 0.4 & 0.4 & 0.4 & 0.3 & 0.3 & 0.3 & 0.3 & 0.3 & 0.3 & 0.2 & 0.3 & 0.3 & 0.3 & 0.4 & 0.4 & 0.4 & 0.4 & 0.4 & 0,4 & 0.4 & \\
\hline & & 乾球温度 (CC) & -23.5 & -23.9 & 24.4 & \begin{tabular}{l|l|}
-24.6 \\
\end{tabular} & -24.95 & -25.1 & -24.7 & $-25.1-2$ & -24.2 & -22.4 & -20.5 & -19.3 & -18.5 & $-18.3=$ & -18.9 & -19.7 & -20.1 & -20.2 & -20.7 & -21.3 & -21.9 & -22.3 & -22.9 & -23.1 & \\
\hline & & 䎦対湿度 $\left(\mathrm{g} / \mathrm{kg}^{\prime}\right)$ & 0.3 & 0.2 & 0.3 & \begin{tabular}{l|l}
0.3 \\
\end{tabular} & 0.2 & 0.3 & 0.3 & 0.2 & 0.3 & 0.3 & 0.3 & 0.4 & 0.4 & 0.3 & 0.3 & 0.3 & 0.2 & 0.3 & 0.3 & 0.2 & 0.3 & 0.3 & 0.2 & 0.3 & \\
\hline & $50 \%$ & 乾球温度( & -22.1 & -22.3 & -22.9 & $-22.9-$ & -23.2 & -23.6 & $-23.7-$ & $-23.9-2$ & $-22.6-$ & $-20.7-$ & $-18.8-$ & $-17.3-$ & -16.7 & -16.7 & $-17.0=$ & $-17.6-$ & $-18.3-$ & -18.9 & $-19.6-$ & -20.1 & -20.8 & -21.2 & -21.5 & -21.9 & \\
\hline & 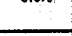 & 䑨対湿度 $\left(\mathrm{g} / \mathrm{kg}^{\prime}\right)$ & 0.3 & 0.3 & 0.3 & 0.3 & 0.3 & 0.3 & 0.3 & 0.3 & 0.4 & 0.4 & 0.4 & 0.4 & 0.4 & 0.4 & 0.4 & 0.4 & 0.3 & 0.4 & 0.4 & 0.3 & 0.4 & 0.4 & 0.3 & 0.4 & \\
\hline & $2.5 \%$ & 乾球温度 ( $\left.{ }^{\circ} \mathrm{C}\right)$ & -0.7 & -0.8 & -1.0 & -1.2 & -1.4 & -1.7 & -1.5 & -1.6 & -0.7 & 0.0 & 0.3 & 0.5 & 0.6 & 0.6 & 0.6 & 0.6 & 0.5 & 0.5 & 0.4 & 0.3 & \begin{tabular}{|l|} 
\\
\end{tabular} & -0.1 & -0.4 & -0.6 & \\
\hline & & 稳対湿度 (g/kg') & 2.9 & 2.9 & 3.0 & 3.0 & 2.9 & 2.9 & 2.9 & 2.8 & 2.9 & 2.8 & 2.6 & 2.6 & 2.5 & 2.4 & 2.4 & 2.4 & 2.4 & 2.5 & 2.6 & 2.7 & 2.9 & 2.9 & 2.9 & 2.9 & 0.0 \\
\hline & $50 \%$ & 乾球温度( $\left.{ }^{\circ} \mathrm{C}\right)$ & \begin{tabular}{l|l}
0.3 \\
\end{tabular} & 0.1 & -0.2 & -0.3 & -0.5 & -0.7 & -0.6 & -0.6 & 0.2 & 0.7 & 1.1 & 1.5 & 1.6 & 1.8 & 1.8 & 1.8 & 1.9 & 1.7 & 1.6 & 1.3 & 1.1 & 0.9 & 0.7 & 0.5 & \\
\hline & 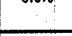 & 秝対湿度 $\left(\mathrm{g} / \mathrm{kg}^{\prime}\right)$ & 3.2 & 3.2 & 3.2 & 3.2 & 3.1 & 3.2 & 3.2 & 3.1 & 3.1 & 3.1 & 2.9 & 3.0 & 2.9 & 2.8 & 2.8 & 2.7 & 2.7 & 2.9 & 3.0 & 3.1 & 3.2 & 3.2 & 3.1 & 3.2 & \\
\hline & $2.5 \%$ & (ic) & 0.7 & 0.1 & -0.4 & -0.5 & -0.8 & -1.2 & -1.0 & -1.4 & -0.8 & 0.3 & 1.7 & 2.9 & 3.4 & 3.9 & 4.0 & 3.9 & 3.7 & 3.5 & 3.1 & 2.8 & 2.4 & 1.9 & 1.5 & 1.1 & \\
\hline & & 絶対湿度 $\left(\mathrm{g} / \mathrm{kg}^{\prime}\right)$ & 3.4 & 3.4 & 3.4 & 3.3 & 3.2 & 3.2 & 3.3 & 3.2 & 3.3 & 3.3 & 3.3 & 3.2 & 3.0 & 2.7 & 2.6 & 2.6 & 2.7 & 3.1 & 3.3 & 3.4 & 3.6 & 3.5 & 3.4 & 3.5 & 2.0 \\
\hline & $5.0 \%$ & 倝球温度('C) & 1.4 & 1.0 & 0.7 & 0.5 & 0.2 & -0.1 & -0.2 & -0.4 & 0.3 & 1.5 & 2.4 & 3.6 & 4.4 & 4.8 & 4.9 & 4.9 & 4.8 & 4.6 & 4.1 & 3.3 & 2.8 & 2.7 & 2.3 & 1.8 & \\
\hline & & 䑨対瀑度 $\left(\mathrm{g} / \mathrm{kg}^{\prime}\right)$ & 3.7 & 3.6 & 3.7 & 3.6 & 3.5 & 3.5 & 3.5 & 3.4 & 3,6 & 3.7 & 3.7 & 3.7 & 3.4 & 3.1 & 3.0 & 2.9 & 3.0 & 3.3 & 3.6 & 3.7 & 3.7 & 3.8 & 3.7 & 3.8 & \\
\hline & $2.5 \%$ & 轻球㳻 & 4.6 & 4,4 & 4.2 & 4.0 & 3.8 & 3.5 & 3.8 & 3.9 & 4.7 & 5.6 & 6.1 & 6.4 & 6.6 & 6.6 & 6.6 & 6.5 & 6.4 & 6.2 & 5.9 & 5.6 & 5.4 & 5.1 & 5.0 & 4.6 & \\
\hline 福州 & & 絶対溹 & 3.1 & 3.1 & 3.1 & 3.1 & 3.0 & 3.1 & 3.0 & 2.9 & 2.9 & 2.8 & 2.7 & 2.7 & 2.9 & 2.9 & 2.9 & 2.8 & 2.8 & 2.9 & 3.0 & 3.0 & 3.1 & 3.2 & 3.1 & 3.1 & 6.0 \\
\hline & $5.0 \%$ & 幹球温度( & 5.5 & 5.3 & 5.0 & 4.9 & 4.7 & 4.5 & 4.8 & 4.7 & 5.6 & 6.5 & 7.0 & 7.4 & 7.6 & 7.6 & 7.6 & 7.4 & 7.2 & 7.0 & 6.7 & 6.4 & 6.1 & 6.0 & 5.8 & 5.6 & \\
\hline & 0.000 & 絻対湿度 $\left(\mathrm{g} / \mathrm{kg}^{\prime}\right)$ & 3.6 & 3.5 & 3.5 & 3.5 & 3.4 & 3.5 & 3.5 & 3.4 & 3.4 & 3.3 & 3.3 & 3.4 & 3.4 & 3.3 & 3.4 & 3.4. & 3.4 & 3.4 & 3.4 & 3.4 & 3.6 & 3.6 & 3.6 & 3.6 & \\
\hline & 2.58 & (iC) & 6.2 & 5.9 & 5.6 & 5.5 & 5.4 & 5.1 & 5.1 & 4.9 & 6.0 & 6.9 & 7.2 & 7.6 & 7.9 & 8.2 & 8.2 & 8.1 & 8.1 & 7.8 & 7.7 & 7.1 & 7.0 & 6.9 & 6.7 & 6.4 & \\
\hline 広州 & & 䡉対淐 & 2.9 & 2.8 & 2.8 & 2.8 & 2.7. & 2.7 & 2.7 & 2.6 & 2.6 & 2.5 & 2.4 & 2.5 & 2.5 & 2.4 & 2.5 & 2.6 & 2.7 & 2.9 & 3.1 & 3.1 & 3.1 & 3.1 & 2.9 & 2.9 & 7.0 \\
\hline & 5.0 & 乾球温度 ( $\left.{ }^{\circ} \mathrm{C}\right)$ & 7.2 & 6.8 & 6.5 & 6.4 & 6.2 & 6.1 & 6.2 & 6.1 & 6.9 & 7.9 & 8.3 & 8.8 & 9.1 & 9.2 & 9.3 & 9.4 & 9.4 & 9.2 & 8.9 & 8.5 & 8.2 & 8.1 & 7.8 & 7.4 & \\
\hline & & 絶対湿 & 3.4 & 3.3 & 3.3 & 3.2 & 3.1 & 3.2 & 3.2 & 3.1 & 3.1 & 3.0 & 2.9 & 2.9 & 3.0 & 3.0 & 3.0 & 3.1 & 3.1 & 3.3 & 3.6 & 3.7. & 3.6 & 3.6 & 3.4 & 3.5 & \\
\hline & $2.5 \%$ & (IC) & -28.4 & -29.0 & -29.4 & -29.9 & -30.4 & -30.6 & $-30.0-$ & $-29.6-2$ & -27.4 & -25.1 & -22.8 & -21.7 & $-20.9-$ & $-20.7-$ & -21.0 & $-21.7-$ & -22.7 & -23.2 & -24.3 & -25.3 & -26.0 & -27.1 & -27.8 & -28.4 & \\
\hline & & 䊉対湿 & 0.2 & 0.1 & 0.2 & 0.2 & 0.1 & 0.2 & 0.2 & 0.1 & 0.2 & 0.3 & 0.2 & 0.3 & 0.3 & 0.3 & 0.3 & 0.3 & 0.2 & 0.3 & 0.3 & 0.2 & 0.2 & 0.2 & 0.2 & 0.2 & \\
\hline & $5.0 \%$ & $\left({ }^{\circ} \mathrm{C}\right)$ & -26.9 & $-27,4$ & -27.9 & -27.9 & -28.3 & $-28.4-$ & -28.1 & $-28.2-2$ & -26.4 & -23.7 & -21.4 & -19.6 & -18.6 & $-18.6-$ & -19.4 & $-20.1-$ & -20.9 & $|-21.7|$ & -22.6 & -23.7 & -24.5 & -25.4 & -26.1 & -26.5 & \\
\hline & $0.08 \mathrm{t}$ & 䎦対湿度( $\left(\mathrm{g} / \mathrm{kg}^{\prime}\right)$ & 0.2 & 0.2 & \begin{tabular}{l|l}
0.2 \\
\end{tabular} & \begin{tabular}{l|l}
0.2 \\
\end{tabular} & 0.2 & 0.2 & 0.2 & 0.2 & 0.3 & 0.3 & \begin{tabular}{l|l}
0.3 \\
\end{tabular} & \begin{tabular}{l|l}
0.4 \\
\end{tabular} & 0.4 & 0.3 & 0.4 & 0.4 & 0.3 & 0.3 & \begin{tabular}{|l|}
0.3 \\
\end{tabular} & \begin{tabular}{l|l}
0.3 \\
\end{tabular} & 0.3 & \begin{tabular}{|l|}
0.3 \\
\end{tabular} & 0.2 & 0.3 & \\
\hline & $2.5 \%$ & 䔶球温度 ( & -19.3 & \begin{tabular}{|l|}
-19.7 \\
\end{tabular} & -20.2 & -20.5 & -20.8 & $-21.3-$ & $-21.3-$ & $-21.6-$ & -20.1 & -18.5 & $-16.6-$ & -15.1 & -13.8 & $-13.3-$ & -13.2 & -13.8 & -14.3 & $|-14.7|$ & -15.6 & -16.5 & -17.2 & -17.9 & -18.5 & \begin{tabular}{|l|}
-19.1 \\
\end{tabular} & \\
\hline & & 䎦対晹 & 0.3 & 0.3 & 0.3 & 0.3 & 0.3 & 0.3 & 0.3 & 0.3 & 0.4 & 0.4 & 0.4 & 0.4 & 0.4 & 0.4 & 0.4 . & 0.4 & 0.3 & 0.4 & 0.4 & 0.3 & 0.4 & 0.4 & 0.3 & 0.3 & 9.0 \\
\hline 浩特 & $5.0 \%$ & (C) & -18.1 & -18.4 & $-18.9 \mid$ & -19.1 & -19.4 & $-19.9-$ & $-20.0-$ & $-20.1-$ & -18.8 & -16.7 & -15.0 & -13.5 & -12.35 & $-11.7-$ & -11.7 & $-11.9-$ & -12.4 & -13.1 & -14.1 & -15.1 & -15.8 & -16.4 & 17.0 & -17.5 & \\
\hline & & 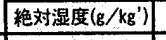 & 0.4 & 0.3 & 0.4 & 0.4 & \begin{tabular}{l|l}
0.3 \\
\end{tabular} & 0.4 & \begin{tabular}{l|l}
0.4 \\
\end{tabular} & 0.3 & 0.4 & 0.5 & 0.4 & 0.5 & 0.5 & 0.4 & 0.5 & 0.5 & 0.4 & 0.4 & \begin{tabular}{|l|}
0.4 \\
\end{tabular} & \begin{tabular}{l|l}
0.4 \\
\end{tabular} & 0.4 & \begin{tabular}{l|l}
0.4 \\
\end{tabular} & 0.3 & 0.4 & \\
\hline & 2.59 & 度( & -8.4 & -9.2 & -9.6 & -10.2 & -10.9 & -11.5 - & $-11.8-$ & $-12,1=$ & -11.3 & -9.9 & \begin{tabular}{|l|}
-8.4 \\
\end{tabular} & \begin{tabular}{|l|}
-6.4 \\
\end{tabular} & -4.6 & -2.7 & \begin{tabular}{|l|}
-1.7 \\
\end{tabular} & \begin{tabular}{|l|}
-0.9 \\
\end{tabular} & -0.8 | & -1.4 & $-2,4$ & \begin{tabular}{|l|}
-3.8 \\
\end{tabular} & \begin{tabular}{|l|} 
\\
\end{tabular} & \begin{tabular}{|l|}
-6.0 \\
\end{tabular} & \begin{tabular}{|l|}
-7.1 \\
\end{tabular} & \begin{tabular}{|l|} 
\\
\end{tabular} & \\
\hline ラ & & 棦对: & 0.4 & 0.3 & 0.4 & 0.4 & 0.3 & 0.4 & 0.4 & 0.3 & 0.4 & 0.3 & 0.3 & 0.3 & 0.3 & 0.2 & 0.2 & 0.2 & 0.2 & 0.2 & 0.2 & 0.2 & 0.3 & 0.3 & 0.2 & 0.3 & -6.0 \\
\hline & $5.0 \%$ & $E\left({ }^{(1 C}\right)$ & -7.3 & -7.9 & -8.7 & $-9.3 \mid$ & -10.0 & -10.5 & $-10.8-$ & -11.4 & -10.4 & -8.9 & -7.1 & -5.1 & $|-3.2|$ & -1.6 & \begin{tabular}{|l|}
$\mid-0.4$ \\
\end{tabular} & 0.2 & 0.2 & -0.3 & \begin{tabular}{|c|} 
\\
\end{tabular} & -2.6 & -3.6 & $-5.0 \mid$ & -6.2 & -6.9 & \\
\hline & & 絶対: & 0.4 & 0.4 & 0.5 & 0.5 & 0.4 & 0.5 & 0.5 & 0.4 & 0.5 & 0.4 & 0.4 & 0.4 & 0.3 & 0.2 & 0.3 & 0.3 & 0.2 & 0.3 & \begin{tabular}{|l|}
0.3 \\
\end{tabular} & 0.2 & 0.3 & 0.4 & 0.3 & 0.4 & \\
\hline & 2.5 & T(OC) & -4.4 & -4.8 & -5.2 & \begin{tabular}{|l|} 
\\
\end{tabular} & -5.6 & -5.8 & -5.3. & \begin{tabular}{|c|}
-5.1 \\
\end{tabular} & -3.7 & \begin{tabular}{l|} 
\\
\end{tabular} & \begin{tabular}{|l|}
-0.9 \\
\end{tabular} & -0.3 & 0.1 & 0.2 & 0.2 & 0.1 & -0.1 & -0.5 & \begin{tabular}{|l|}
-0.9 \\
\end{tabular} & \begin{tabular}{|l|}
-1.8 \\
\end{tabular} & -2.4 & \begin{tabular}{|l|} 
\\
\end{tabular} & \begin{tabular}{|l|}
-3.4 \\
\end{tabular} & -4.0 & \\
\hline 南 & & $\left(\mathrm{g} / \mathrm{kg}^{\prime}\right)$ & 1.8 & 1.8 & 1.8 & 1.8 & 1.8 & 1.8 & 1.8 & 1.7 & 1.7 & 1.6 & 1.4 & 1.4 & 1.4 & 1.3 & 1.3 & 1.4 & 1.3 & 1.5 & 1.6 & 1.6 & 1.7 & 1.7 & 1.7 & 1.8 & -3.0 \\
\hline & $5.0 \%$ & (C) & -3.1 & -3.5 & -4.0 & -4.2 & -4.5 & -4.6 & -4.3 & -4.2 & -2.6 & -1.0 & 0.1 & 0.7 & 1.1 & 1.2 & 1.3 & 1.1 & 0.9 & 0.5 & \begin{tabular}{|l|}
$\mid-0.2$ \\
\end{tabular} & -0.9 & -1.4 & -1.8 & -2.3 & -2.9 & \\
\hline & & 乘対: & 2.0 & 2.0 & 2.1 & 2.1 & 2.0 & 2.0 & 2.0 & 2.0 & 2.0 & 1.8 & 1.7 & 1.6 & 1.6 & 1.5 & 1.6 & 1.6 & 1.6 & 1.7 & 1.8 & 1.9 & 2.0 & 2.0 & 2.0 & 2.0 & \\
\hline & 25 & $\left({ }^{\circ}\right)$ & -2.6 & -3.1 & -3.5 & \begin{tabular}{|l|}
-3.4 \\
\end{tabular} & -3.5 & \begin{tabular}{|c|}
-3.7 \\
\end{tabular} & -3.1 & -3.0 & -2.0 & -0.9 & 0.3 & 0.9 & 1.3 & 1.3 & 1.1 & 0.8 & 0.7 & 0.3 & \begin{tabular}{|l|}
-0.4 \\
\end{tabular} & \begin{tabular}{|l|}
-1.0 \\
\end{tabular} & \begin{tabular}{|l|}
-1.4 \\
\end{tabular} & \begin{tabular}{|l|}
-1.7 \\
\end{tabular} & \begin{tabular}{|l|}
-1.9 \\
\end{tabular} & \begin{tabular}{|l|} 
\\
\end{tabular} & \\
\hline 上海 & 2.000 & 䎦対湿度 $\left(\mathrm{g} / \mathrm{kg}^{\prime}\right)$ & 1.9 & 1.8 & 1.9 & 1.9 & 1.8 & 1.9 & 1.8 & 1.8 & 1.7 & 1.6 & 1.5 & 1.4 & 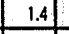 & 1.4 & 1.4 & 1.4 & 1.3 & 1.5 & 1.6 & 1.7 & 1.8. & 1.8 & 1.8 & 1.9 & -2.0 \\
\hline & $5.0 \%$ & & -1.4 & -1.6 & -2.2 & -2.3 & $-2.5 \mid$ & -2.6 & -2.2 & $-2.0 \mid$ & -0.9 & 0.3 & 1.4 & 21 & 2.3 & 2.4 & 2.3 & 2.0 & 1 & 1.3 & 0.8 & 0.2 & -0.2 & -0.4 & -0.7 & -1.2 & \\
\hline & & 絶対 & 2.2 & 2.1 & 2.2 & 2.2 & 2.1 & 2.2 & 2.2 & 2.1 & 2.1 & 1.9 & 1.8 & 1.7 & 1.7 & 1.6 & $\begin{array}{l}1.6 \\
\end{array}$ & 1.6 & 1.7 & 1.8 & 1.9 & 2.0 & 2.1 & 2.1 & 2.1 & 2.2 & \\
\hline & 25 & 倝球温庭 $\left({ }^{\circ} \mathrm{C}\right)$ & -20.0 & \begin{tabular}{|l|}
-20.4 \\
\end{tabular} & -21.0 & -21.5 & -21.7 & $-22.0-$ & $-21.9-$ & $-22.0-$ & -21.8 & -19.0 & -16.0 & -14.6 & -13.9 & -13.3 & \begin{tabular}{|l|}
-13.7 \\
\end{tabular} & -13.8 & -14.4 & $\mid-15.1$ & -16.0 & -17.3 & -17.8 & -18.5 & -19.0 & \begin{tabular}{|l|} 
\\
\end{tabular} & \\
\hline & 2.000 & 绝对湿度( $\left(g / \mathrm{kg}^{\prime}\right)$ & 0.4 & 0.3 & 0.4 & 0.4 & \begin{tabular}{|l|} 
\\
\end{tabular} & 0.4 & 0.4 & 0.3 & 0.4 & 0.4 & 0.4 & 0.4 & 0.4 & 0.3 & 0.3 & 0.3 & 0.3 & 0.4 & 0.4 & 0.3 & 0.4 & 0.4 & 0.3 & 0.4 & -1 \\
\hline & $5.0 \%$ & (C) & \begin{tabular}{|l|}
-18.4 \\
\end{tabular} & \begin{tabular}{|l|}
-19.0 \\
\end{tabular} & -19.4 & -19.6 & -20.0 & $-20.3-$ & $-20.2-$ & $-20.7-$ & -19.2 & -16.8 & -14.5 & -13.1 & -12.2 & -12.0 & -12.2 & -12.4 & -12.9 & -13.5 & $\mid-14.1$ & -15.1 & -15.9 & -16.6 & -17.3 & -18.0 & \\
\hline & $3.0 \%$ & $\left(\mathrm{~kg}^{\prime}\right)$ & 0.4 & 0.4 & 0.4 & 0.4 & 0.4 & 0.4 & 0.4 & 0.4 & 0.4 & 0.5 & 0.4 & \begin{tabular}{|l|}
0.5 \\
\end{tabular} & \begin{tabular}{l|l}
0.4 \\
\end{tabular} & \begin{tabular}{|l|}
0.3 \\
\end{tabular} & 0.4 & \begin{tabular}{l|l}
0.4 \\
\end{tabular} & \begin{tabular}{l|l}
0.4 \\
\end{tabular} & 0.4 & 0.4 & \begin{tabular}{l|l}
0.4 \\
\end{tabular} & 0.4 & 0.5 & 0.4 & 0.4 & \\
\hline & 2.59 & c) & -9.9 & -9.8 & $\mid-10.3$ & -10.4 & -10.6 & $-10.9-$ & $-10.8-$ & \begin{tabular}{|l|}
-10.8 \\
\end{tabular} & -9.5 & \begin{tabular}{|l|l|}
-7.9 \\
\end{tabular} & \begin{tabular}{|l|}
-6.6 \\
\end{tabular} & -5.6 & $|-5.1|$ & -4.8 & \begin{tabular}{|l|} 
\\
\end{tabular} & -5.0 & \begin{tabular}{|l|l|} 
& -5.4 \\
\end{tabular} & $|-5.7|$ & \begin{tabular}{|c|}
-6.4 \\
\end{tabular} & \begin{tabular}{|l|} 
\\
\end{tabular} & \begin{tabular}{|l|} 
\\
\end{tabular} & -8.9 & -9.8 & \begin{tabular}{|l|} 
\\
\end{tabular} & \\
\hline & & 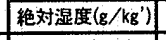 & 0.4 & 0.3 & 0.4 & 0.4 & 0.3 & 0.4 & 0.4 & 0.3 & 0.4 & 0.4 & \begin{tabular}{l|l}
0.3 \\
\end{tabular} & 0.3 & 0.3 & 0.3 & 0.3 & 0.3 & 0.3 & 0.4 & 0.4 & 0.4 & 0.4 & 0.4 & 0.3 & 0.4 & -9.0 \\
\hline & $5.0 \%$ & (IC) & -8.7 & -8.7 & -9.1 & \begin{tabular}{|l|}
-9.0 \\
\end{tabular} & \begin{tabular}{|l|l|} 
& -9.3 \\
\end{tabular} & -9.6 & -9.6 & \begin{tabular}{|l|}
-9.6 \\
\end{tabular} & -8.4 & -6.7 & \begin{tabular}{|l|}
-5.3 \\
\end{tabular} & -4.4 & \begin{tabular}{|l|} 
\\
\end{tabular} & \begin{tabular}{|l|} 
\\
\end{tabular} & -3.3 & \begin{tabular}{|l|}
-3.6 \\
\end{tabular} & $\begin{array}{l}-3.9 \\
\end{array}$ & -4.4 & \begin{tabular}{|l|} 
\\
\end{tabular} & -6.2 & -7.0 & -7.8 & -8.7 & \begin{tabular}{|l|} 
\\
\end{tabular} & \\
\hline & & $\left./ \mathrm{kg}^{\prime}\right)$ & 0.5 & 0.5 & 0.5 & 0.5 & $\begin{array}{ll}0.5 \\
\end{array}$ & 0.5 & 0.5 & 0.4 & 0.5 & \begin{tabular}{l|l}
0.5 \\
\end{tabular} & 0.4 & 0.5 & 0.5 & \begin{tabular}{l|l}
0.4 \\
\end{tabular} & 0.5 & 0.5 & 0.4 & 0.5 & 0.5 & 0.5 & 0.6 & 0.6 & 0.5 & 0.5 & \\
\hline & 2.5 & ('C) & \begin{tabular}{|l|}
-22.3 \\
\end{tabular} & -22.3 & -22.7 & -22.4 & $-22,3$ & $-22.6-$ & $-22,4$ & -22.2 & -22.3 & -21.7 & -20.7 & -19.5 & -18.5 & -17.6 & \begin{tabular}{|l|}
-17.4 \\
\end{tabular} & -17.5 & -17.8 & -18.5 & -19.5 & -20.2 & -20.7 & -21.0 & \begin{tabular}{|l|} 
\\
\end{tabular} 1.5 & -22.0 & \\
\hline 鳥魯 & & $\left./ / \mathrm{kg}^{\prime}\right)$ & 0.4 & 0.4 & \begin{tabular}{l|l}
0.4 \\
\end{tabular} & 0.4 & 0.4 & 0.4 & 0.4 & 0.4 & \begin{tabular}{l|l}
0.4 \\
\end{tabular} & 0.4 & 0.4 & 0.5 & 0.6 & 0.5 & 0.6 & 0.6 & 0.5 & 0.6 & 0.6 & 0.5 & 0.5 & 0.5. & 0.4 & 0.5 & \\
\hline 木 & $5.0 \%$ & 乾球温度( & \begin{tabular}{|l|}
-19.7 \\
\end{tabular} & \begin{tabular}{|l|}
-20.1 \\
\end{tabular} & $\mid-20.4$ & -20.2 & -20.4 & $-20.6-$ & -20.5 & $-20.7-$ & -20.6 & \begin{tabular}{|l|}
-20.1 \\
\end{tabular} & \begin{tabular}{|l|}
-18.9 \\
\end{tabular} & -17.5 & -16.3 & -15.2 & \begin{tabular}{|l|}
14.7 \\
\end{tabular} & -14.9 & -15.7 & \begin{tabular}{|l|}
16.3 \\
\end{tabular} & -17.3 & -18.0 & -18.7 & -19.0 & -19.3 & -19.9 & \\
\hline & & 鶴対湿度 $\left(\mathrm{g} / \mathrm{kg}^{\prime}\right)$ & 0.6 & 0.5 & 0.6 & 0.5 & 0.5 & 0.5 & \begin{tabular}{l|l}
0.5 \\
\end{tabular} & 0.5 & 0.5 & 0.5 & 0.5 & \begin{tabular}{l|l}
0.7 \\
\end{tabular} & 0.7 & 0.7 & 0.8 & 0.8 & 0.7 & 0.7 & 0.7 & 0.6 & 0.7 & 0.6 & 0.5 & 0.6 & \\
\hline & $2.5 \%$ & & -2.2 & -2.5 & -3.1 & -3.0 & $\mid-3.1$ & \begin{tabular}{|c|}
-3.2 \\
\end{tabular} & -3.1 & \begin{tabular}{|c|}
-3.3 \\
\end{tabular} & -2.2 & \begin{tabular}{|l|}
-1.2 \\
\end{tabular} & \begin{tabular}{|c|}
-0.4 \\
\end{tabular} & 0.0 & 0.3 & 0.4 & 0.4 & 0.5 & 0.4 & 0.3 & 0.0 & \begin{tabular}{|l|}
-0.4 \\
\end{tabular} & \begin{tabular}{|l|} 
\\
\end{tabular} & -1.0 & \begin{tabular}{|l|}
-1.4 \\
\end{tabular} & \begin{tabular}{|l|}
-1.9 \\
\end{tabular} & \\
\hline & & $\left./ \mathrm{kg}^{\prime}\right)$ & 2.2 & 2.2. & 2.2 & 2.2 & 2.1 & 2.2 & 2.2 & 2.0 & 2.0 & 1.9 & 1.8 & 1.7 & 1.7 & 1.6 & 1.6 & 1.6 & 1.7 & 1.9 & 2.0 & $2.1]$ & 2.2 & 2.2 & 2.2. & 2.2 & \\
\hline & 5.0 & (C) & -1.2 & -1.4 & -1.8 & \begin{tabular}{|l|} 
\\
\end{tabular} & \begin{tabular}{|l|l|} 
& -2.2 \\
\end{tabular} & -2.3 & \begin{tabular}{|l|}
-2.1 \\
\end{tabular} & -2.2 & -1.3 & -0.1 & 0.6 & 1.0 & 1.4 & 1.6 & 1.7 & 1.5 & 1.6 & 1.3 & 0.9 & 0.4 & 0.0 & -0.2 & -0.5 & $\mid-0.9$ & \\
\hline & & 䎦対湿度 $\left(\mathrm{g} / \mathrm{kg}^{\prime}\right)$ & 2.5 & 2.4 & 2.5 & 2.5 & \begin{tabular}{|l|l|} 
& 2.4 \\
\end{tabular} & 2.4 & 2.4 & 2.4 & 2,3 & 2.2 & 2.1. & 2.1 & 1.9 & 1.8 & 1.8 & 1.8 & 1.9 & 2.11 & 2.3. & 2.4 & 2.5 & 2.5 & 2.4 & 2.5 & \\
\hline & $2.5 \%$ & & -5.2 & -5.7 & -6.1 & -6.3 & \begin{tabular}{|l|} 
\\
\end{tabular} & \begin{tabular}{|l|}
-7.1 \\
\end{tabular} & -7.0 & -7.2 & \begin{tabular}{|l|}
-6.4 \\
\end{tabular} & -5.2 & \begin{tabular}{|l|}
-4.1 \\
\end{tabular} & \begin{tabular}{|c|}
-3.2 \\
\end{tabular} & $-2.4 \mid$ & \begin{tabular}{|l|}
-1.8 \\
\end{tabular} & -1.6 & \begin{tabular}{|l|}
-1.6 \\
\end{tabular} & -1.7 & -2.1 & \begin{tabular}{|c|}
-2.9 \\
\end{tabular} & -3.5 & -3.8 & -4.3 & \begin{tabular}{|l|}
-4.7 \\
\end{tabular} & -5.1 & \\
\hline & & 絶鳼 & 1.4 & 1.3 & 1.4 & 1.4 & \begin{tabular}{ll|}
4 & 1.3 \\
\end{tabular} & 1.3 & 1.3 & 1.2 & 1.2 & 1.1 & 0.9 & 0.9 & 0.9 & 0.9 & 0.9 & 1.0 & 1.0 & 1.1. & 1.2 & 1.3 & 14 & 1.4 & 1.4 & 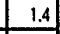 & \\
\hline & & 輷球温度( & -4.3 & -4.6 & -5.0 & -5.2 & \begin{tabular}{|l|l|}
2 & -5.5 \\
\end{tabular} & \begin{tabular}{|l|}
-5.9 \\
\end{tabular} & -5.8 & \begin{tabular}{|l|} 
\\
\end{tabular} & \begin{tabular}{|l|}
-5.2 \\
\end{tabular} & \begin{tabular}{|l|}
-4.0 \\
\end{tabular} & \begin{tabular}{|l|} 
\\
\end{tabular} & -2.0 & $\mid-1.3$ & \begin{tabular}{|l|}
-0.9 \\
\end{tabular} & \begin{tabular}{|l|}
-0.7 \\
\end{tabular} & -0.6 & \begin{tabular}{|l|}
-0.8 \\
\end{tabular} & \begin{tabular}{|l|} 
\\
\end{tabular} & \begin{tabular}{|l|}
-1.6 \\
\end{tabular} & \begin{tabular}{|l|}
-2.4 \\
\end{tabular} & \begin{tabular}{|l|}
-3.0 \\
\end{tabular} & -3.1 & \begin{tabular}{|l|} 
\\
\end{tabular} & -4.0 & \\
\hline & & 舥対湿度 $\left(\mathrm{g} / \mathrm{kg}^{\prime}\right)$ & 1.6 & 1.5 & 1.6 & 1.6 & \begin{tabular}{|l|l|}
6 & 1.5 \\
\end{tabular} & 1.5 & 1.5 & 1.4 & 1.4 & 1.4 & 1.2 & 1.2 & 1.2 & 1.1 & 1.1 & 1.1 & 1.1 & 1.3 & 1.4 & 1.5 & 1.6 & 1.6 & 1.6 & 1.6 & \\
\hline & 2.5 & 庭 & -6.5 & -6.9 & -7.3 & -7.5 & \begin{tabular}{|l|l|}
5 & -8.0 \\
\end{tabular} & \begin{tabular}{|c|}
-8.2 \\
\end{tabular} & \begin{tabular}{l|}
-7.9 \\
\end{tabular} & -8.3 & -6.5 & \begin{tabular}{|c|}
-4.8 \\
\end{tabular} & \begin{tabular}{|r|}
-3.5 \\
\end{tabular} & \begin{tabular}{|l|}
-2.7 \\
\end{tabular} & $|-2.3|$ & \begin{tabular}{|l|}
-2.1 \\
\end{tabular} & -2.0 & \begin{tabular}{|l|}
-2.0 \\
\end{tabular} & -2.2 & $-2,6$ & -3.2 & -4.2 & \begin{tabular}{|l|} 
\\
\end{tabular} & -5.2 & \begin{tabular}{|l|} 
\\
\end{tabular} & $\mid-6.1$ & \\
\hline & & 䎦对湿度 $\left(\mathrm{g} / \mathrm{kg}^{\prime}\right)$ & 0.9 & 0.8 & 0.9 & 0.9 & $0.8 \mathrm{f}$ & 0.9 & 0.9 & 0.8 & 0.8 & 0.8 & 0.7 & 0.7 & 0.6 & 0.5 & 0.6 & 0.6 & 0.6 & 0.7 & 0.8 & 0.8 & 0.9 & 0.9 & 0.9 & 0.9 & \\
\hline & & 乾球温度( & -5.5 & -5.8 & -6.3 & \begin{tabular}{|l|} 
\\
\end{tabular} & \begin{tabular}{|l|l|}
5 & -6.7 \\
\end{tabular} & \begin{tabular}{|l|}
-7.0 \\
\end{tabular} & -6.9 & \begin{tabular}{|l|}
-7.0 \\
\end{tabular} & \begin{tabular}{|l|} 
\\
\end{tabular} & $-3.5 \mid$ & -2.3 & \begin{tabular}{|l|}
$\mid-1.5$ \\
\end{tabular} & $|-1.1|$ & \begin{tabular}{|l|} 
\\
\end{tabular} & \begin{tabular}{|l|} 
\\
\end{tabular} & -1.0 & $|-1.1|$ & \begin{tabular}{|l|}
-1.6 \\
\end{tabular} & -2.2 & $|-3.1|$ & \begin{tabular}{|l|} 
\\
\end{tabular} & -4.2 & $-4.7 \mid$ & -5.2 & \\
\hline & & 孫刘湿度 $\left(\mathrm{g} / \mathrm{kg}^{\prime}\right)$ & 1.2 & 1.1 & 1.2 & 1.1 & \begin{tabular}{l|l|}
1 & 1.0 \\
\end{tabular} & 1.1 & 1.1 & 1.0 & 1.0 & 0.9 & 0.81 & $\begin{array}{l}0.8 \\
\end{array}$ & \begin{tabular}{|l|} 
\\
\end{tabular} & 0.7 & 0.8 & 0.8 & 0.8 & I & 1.0 & 1.0 & 2 & 1.2 & \begin{tabular}{|l|}
1.1 \\
\end{tabular} & 1.2 & \\
\hline
\end{tabular}


表5 各地における冷房設計用時刻別温湿度 (夏季)

\begin{tabular}{|c|c|c|c|c|c|c|c|c|c|c|c|c|c|c|c|c|c|c|c|c|c|c|c|c|c|c|c|}
\hline 䧇 & & 北京時間 & & & & & & & & & & & & & & & & & & & & & & & & 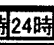 & 噺設副温庭 \\
\hline \multirow{4}{*}{ 京 } & & 乾球温度(跒) & 27.3 & 26.9 & 26.5 & 26.3 & 26.0 & 26.1 & 26.6 & 27.6 & 29.0 & 30.4 & 31.7 & 33.01 & 33.9 & 34.4 & 35.0 & 35.1 & 34.9 & 33.9 & 32.8 & 31.7 & 30.6 & 29.4 & 28.6 & 28.0 & \\
\hline & & 絶対湿度 $\left(\mathrm{g} / \mathrm{kg}^{\prime}\right)$ & 19.6 & 19.4 & 19.4 & 19.3 & 19.1 & 19.1 & 19.2 & \begin{tabular}{|l|}
19.3 \\
\end{tabular} & 19.4 & \begin{tabular}{|c|}
19.6 \\
\end{tabular} & 19.5 & 19.5 & 19.6 & 19.7 & 19.7 & 19.7 & $\mid$\begin{tabular}{|c|}
19.7 \\
\end{tabular} & $\mid$\begin{tabular}{|c|}
19.7 \\
\end{tabular} & 19.8 & 19.9 & 19.8 & \begin{tabular}{|l|}
19.7 \\
\end{tabular} & 19.8 & 19.7 & \\
\hline & 5 & 乾球温度 ( $\left.{ }^{\circ} \mathrm{C}\right)$ & 26.7 & 26.2 & 25.7 & 25.4 & 25.2 & 25.3 & 26.0 & 26.9 & 28.2 & 29.7 & 31.0 & 32.1 & 33.1 & 33.8 & 34.2 & 34.1 & 33.8 & 33.0 & 31.9 & 30.7 & \begin{tabular}{|l|}
29.8 \\
\end{tabular} & 28.7 & 28.0 & 27.3 & 33.2 \\
\hline & & 絶対湿度 $\left(\mathrm{g} / \mathrm{kg} \mathrm{g}^{\prime}\right)$ & 18.8 & 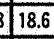 & 18.5 & 18.4 & 18.2 & 18.3 & 18.4 & 18.5 & 18.6 & 18.8 & 18.7 & 18.8 & 18.8 & 18.7 & 18.7 & 18.8 & 18.6 & 18.7 & 18.8 & 18.9 & 18.9 & 18.9 & 18.8 & 18.8 & \\
\hline & & 乾球温度 $\left({ }^{\circ} \mathrm{C}\right)$ & 24.2 & 23.9 & 23.6 & 23.6 & 23.5 & 23.9 & 25.1 & \begin{tabular}{|l|}
26.3 \\
\end{tabular} & 27.8 & 29.0 & 30.0 & \begin{tabular}{l|l|l|}
30.5 & \\
\end{tabular} & 31.0 & 31.6 & 31.7 & 31.6 & 31.1 & 29.8 & 28.6 & 27.2 & 26.5 & 25.7 & 25.2 & 24.5 & \\
\hline & & 絶対湿度 $\left(\mathrm{g} / \mathrm{kg}^{\prime}\right)$ & 17.0 & 16.8 & 16.8 & 16.7 & 16.5 & 16.7 & 16.9 & 17.3 & 17.5 & 17.6 & 17.6 & 17.6 & 17.7 & 17.7 & 17.7 & 17.9 & 17.8 & |17.7 & 17.6 & 17.6 & 17.4 & 17.3 & $17: 1$ & 17.1 & \\
\hline & $50 \%$ & 乾球温度 $\left({ }^{\circ} \mathrm{C}\right)$ & 23.6 & 6. & 22.9 & 22.7 & 22.7 & 23.1 & 24.4 & 25.4 & 26.7 & 27.9 & 28.8 & \begin{tabular}{ll|l}
29.6 & \\
\end{tabular} & 30.1 & 30.6 & 30.8 & 30.7 & 30.0 & 28.9 & 27.6 & 26.3 & 25.6 & 24.9 & 24.4 & 23.9 & \\
\hline & & 絶対湿度 $\left(\mathrm{g} / \mathrm{kg}^{\prime}\right)$ & 16.0 & 015.9 & 15.9 & 15.7 & 15.6 & 15.8 & 16.1 & 16.3 & 16.6 & 16.7 & 16.7 & 16.8 & 16.7 & 16.7 & 16.9 & 17.0 & 16.9 & 16.9 & 16.9 & 16.7 & 16.6 & 16.5 & 16.3 & 16.1 & \\
\hline & & 乾球温度 $\left({ }^{\circ} \mathrm{C}\right)$ & 29.8 & 29.5 & 29.0 & 28.8 & 28.7 & 28.7 & 29.6 & 30.2 & 31.6 & 33.0 & 34.3 & \begin{tabular}{ll|}
35.2 \\
\end{tabular} & 35.8 & 36.2 & 36.7 & 36.8 & 36.3 & 35.5 & 34.3 & 33.0 & 32.1 & 31.4 & 30.9 & 30.2 & \\
\hline & & 絶対湿度 $\left(\mathrm{g} / \mathrm{kg}^{\prime}\right)$ & 21.9 & 21.7 & 21.7 & 21.6 & 21.4 & 21.5 & 21.6 & 21.6 & 21.7 & 21.7 & 21.7 & 21.62 & 21.7. & 21.7 & 21.8 & 21.9 & 21.8 & 21.9 & 22.0 & 22.3 & 22.1 & 22.0 & 22.1 & 2.0 & \\
\hline & $50 \%$ & 乾球温度( $\left.{ }^{\circ} \mathrm{C}\right)$ & 29.3 & 29.0 & 28.6 & 28.4 & 28.2 & 28.2 & 29.1 & \begin{tabular}{|l|}
29.8 \\
\end{tabular} & 31.1 & 32.4 & 33.6 & 34.5 & 35.2 & 35.7 & 36.0 & 36.2 & 35.8 & \begin{tabular}{|l|l|}
34.8 \\
\end{tabular} & 33.6 & 32.4 & 31.6 & 30.9 & 30.4 & 29.7 & \\
\hline & & 䊉対湿度 $\left(\mathrm{g} / \mathrm{kg}^{\prime}\right)$ & 21.2 & 21.2 & 21.1 & 21.0 & 20.8 & 21.0 & 21.0 & 21.0 & 21.1 & 21.1 & 21.1 & 21.2 & \begin{tabular}{|l|}
21.2 \\
\end{tabular} & 21.2 & 21.1 & 21.2 & 21.3 & 21.2 & 21.4 & 21.6 & 21.5 & 21.5 & 21.6 & 21.4 & \\
\hline & & 乾球温度( $\left.{ }^{\circ} \mathrm{C}\right)$ & 26.5 & 526.2 & 25.7 & 25.5 & 25.4 & 25.3 & 25.6 & 25.9 & 26.8 & 28.4 & 30.1 & 31.3 & 31.9 & 32.3 & 32.7 & 33.0 & 33.0 & 32.3 & 31.2 & 29.8 & 29.1 & 28.2 & 27.6 & 27.0 & \\
\hline & & 䡮対湿度 $\left(\mathrm{g} / \mathrm{kg}^{\prime}\right)$ & 19.8 & 19.5 & 19.4 & 19.2 & 19.0 & 19.0 & 19.1 & \begin{tabular}{|l|}
19.3 \\
\end{tabular} & 19.5 & 19.8 & 20.0 & 20.12 & 20.3 & 20.4 & 20.4 & 20.4 & 20.5 & 21.0 & 21.1 & 21.2 & 21.0 & 20.6 & 20.4 & $\overline{02}$ & \\
\hline & $50 \%$ & 乾球温度("C) & 26.0 & 25.7 & 25.3 & 25.0 & 24.9 & 24.8 & 25.1 & 25.3 & 26.3 & 27.9 & 29.3 & 30.5 & 31.2 & 31.7 & 32.1 & 32.5 & 32.2 & 31.4 & 30.4 & 29.3 & 28.5 & 27.6 & 27.0 & 26.5 & \\
\hline & & 舥対湿度 $\left(\mathrm{g} / \mathrm{kg}^{\prime}\right)$ & 19.4 & 19.1 & 19.0 & 18.8 & 18.5 & 18.5 & 18.5 & 18.6 & 18.9 & 19.0 & 19.2 & \begin{tabular}{|l|l|}
19.6 & 1 \\
\end{tabular} & 19.7 & 19.8 & 19.7 & \begin{tabular}{|c|}
19.7 \\
\end{tabular} & 19.7 & 20.0 & 20.3 & 20.5 & 20.3 & 20.1 & 19.8 & 19.6 & \\
\hline & & 乾球温度( $\left.{ }^{\circ} \mathrm{C}\right)$ & 28.5 & 28.3 & 27.9 & 27.9 & 27.8 & 27.9 & 29.0 & 29.8 & 31.2 & 32.8 & 34.2 & \begin{tabular}{|l|l|}
35.6 & 3 \\
\end{tabular} & 36.6 & 36.9 & 36.8 & 36.2 & 35.0 & 33.5 & 31.8 & 30.5 & 29.9 & 29.4 & 29.1 & 28.7 & \\
\hline & & 秝対湿度 $(\mathrm{g} / \mathrm{kg})$ & 20.6 & 20.5 & 20.6 & 20.6 & 20.5 & 20.7 & 21.0 & 21.1 & 21.3 & \begin{tabular}{|l|}
21.5 \\
\end{tabular} & 21.5 & 21.6 & 21.9 & 21.9 & 22.1 & 22.1 & 22.1 & 22.0 & 21.5 & 21.1 & 21.0 & 20.9 & 20.6 & 20.7 & \\
\hline & $50 \%$ & 乾球温度( $\left.{ }^{\circ} \mathrm{C}\right)$ & 28.1 & 27.9 & 27.5 & 27.5 & 27.4 & 27.6 & 28.7 & 29.4 & 30.8 & 32.3 & 33.8 & 35.0 & 35.9 & 36.4 & 36.2 & 35.5 & 34.4 & 32.9 & 31.3 & 30.1 & 29.5 & 29.1 & 28.8 & 28.3 & \\
\hline & & 绝対湿度 $\left(\mathrm{g} / \mathrm{kg}^{\prime}\right)$ & 20.4 & 20.3 & 20.3 & 20.3 & 20.3 & 20.4 & 20.6 & 20.8 & 21.0 & 21.0 & 20.9 & 21.1 & 21.3 & 21.5 & 21.6 & 21.8 & 21.8 & 21.5 & 21.1 & 20.7 & 20.6 & 20.6 & 20.4 & 20.4 & \\
\hline & & 乾球温 & 29.1 & 28.9 & 28.5 & 28.3 & 28.2 & 28.3 & 29.1 & 29.6 & 30.8 & 31.9 & 33.1 & 34.0 & 34.6 & 34.8 & 35.2 & 35.2 & 34.8 & 34.0 & 32.8 & 31.7 & 31.1 & 30.4 & 29.9 & 29.4 & \\
\hline & & 乘対湿度 $(\mathrm{g} / \mathrm{kg})$ & 21.9 & 21.8 & 21.9 & 21.8 & 21.6 & 21.7 & 21.8 & 22.0 & 22.0 & 22.0 & 21.7 & \begin{tabular}{|l|l|}
21.7 \\
\end{tabular} & 21.9 & 21.7 & 21.9 & 21.9 & 22.0 & 22.1 & 22.2 & 22.2 & 22.1 & 22.0 & 22.0 & 22.0 & \\
\hline & $50 \%$ & 乾球温度( $\left.{ }^{\circ} \mathrm{C}\right)$ & 28.7 & 28.5 & 28.1 & 28.0 & 27.9 & 28.0 & 28.7 & 29.2 & 30.3 & 31.5 & 32.6 & 33.4 & 34.1 & 34,4 & 34.6 & 34.8 & 34.5 & 33.6 & 32.4 & 31.3 & 30.6 & 29.9 & 29.4 & 28.9 & \\
\hline & & 絶対湿度 $\left(\mathrm{g} / \mathrm{kg} \mathrm{g}^{\prime}\right)$ & 21.6 & 321.6 & 21.5 & 21.5 & 21.3 & 21.5 & 21.5 & 21.6 & 21.6 & 21.6 & 21.3 & 21.3 & 21.5 & 21.3 & 21.3 & 21.5 & 21.6 & \begin{tabular}{|l|}
21.7 \\
\end{tabular} & 21.8 & 22.0 & 21.9 & 21.7 & 21.7 & 21.6 & \\
\hline & & 乾球温度 & 23.5 & 23.4 & 23.0 & 22.8 & 22.6 & 23.0 & 24.6 & 26.2 & 27.9 & \begin{tabular}{|l|}
29.3 \\
\end{tabular} & 29.8 & 30.4 & 31.0 & 31.4 & 31.8 & 31.8 & 30.9 & \begin{tabular}{|l|}
29.7 \\
\end{tabular} & 28.1 & 26.7 & 25.8 & 25.2 & 24.5 & 23.9 & \\
\hline & & 秝対湿度 $\left(\mathrm{g} / \mathrm{kg}^{\prime}\right)$ & 16.1 & 15.8 & 15.8 & 15.9 & 15.8 & 16.1 & 16.6 & 16.8 & 17.1 & \begin{tabular}{|l|}
17.4 \\
\end{tabular} & 17.2 & 17.3 & 17.2 & 17.0 & 17.2 & 17.3 & 17.4 & \begin{tabular}{|l|}
17.4 \\
\end{tabular} & 17.4 & 17.4 & 17.2 & 16.9 & 16.5 & 16.4 & \\
\hline & & 乾球温度 ( $\left.{ }^{\circ} \mathrm{C}\right)$ & 22.5 & 22.2 & 21.8 & 21.7 & 21.7 & 22.2 & 23.9 & 25.3 & 27.1 & \begin{tabular}{|l|}
28.2 \\
\end{tabular} & 28.9 & 29.5 & 29.9 & 30.3 & 30.6 & 30.5 & 29.9 & 28.6 & 27.2 & 25.8 & 24.9 & 24.1 & 23.5 & 22.8 & \\
\hline & & 絶対湿度 $\left.(\mathrm{g} / \mathrm{kg})^{\prime}\right)$ & 15.4 & 15.1 & 15.1 & 15.0 & 15.0 & 15.3 & 15.6 & 16.1 & 16.3 & 16.4 & 16.4 & 16.3 & 16.2 & 16.3 & 16.3 & 16.4 & 16.4 & 16.3 & 16.5 & 16.3 & 16.1 & 15.9 & 15.6 & 15.5 & \\
\hline & 2 & 乾球温度( $\left.{ }^{(} \mathrm{C}\right)$ & 23.0 & 22.6 & 21.9 & 21.3 & 21.2 & 21.2 & 22.7 & 24.2 & 25.9 & 27.5 & 29.0 & 30.1 & 30.9 & 31.6 & 32.1 & 32.4 & 32.3 & 31.6 & 30.5 & 29.2 & 27.8 & 26.0 & 24.8 & 23.8 & \\
\hline & & 絶対湿度 $\left.(\mathrm{g} / \mathrm{kg})^{\prime}\right)$ & 13.3 & 13.1 & 13.1 & 12.9 & 12.8 & 12.8 & 12.9 & 13.0 & 13.3 & \begin{tabular}{|l|}
13.4 \\
\end{tabular} & 13.4 & 13.6 & 13.7 & 13.7 & 13.7 & 13.8 & 13.6 & 13.8 & 13.6 & 13.6 & 13.5 & 13.4 & 13.5 & 13.3 & \\
\hline & & 乾球温度 ( $\left.{ }^{\circ} \mathrm{C}\right)$ & 22.2 & 21.6 & 20.9 & 20.5 & 20.2 & 20.5 & 21.8 & 23.2 & 25.0 & 26.4 & 27.6 & 28.7 & 29.7 & 30.4 & 30.9 & 31.1 & 31.0 & 30.5 & 29.5 & 28.3 & 26.9 & 25.1 & 24.1 & [23.2. & \\
\hline & & 绝対湿度 $\left(\mathrm{g} / \mathrm{kg} \mathrm{g}^{\prime}\right)$ & 12.6 & 12.5 & 12.4 & 12.3 & 12.1 & 12.2 & 12.3 & 12.3 & 12.5 & 12.6 & 12.6 & 12.7 & 12.9 & 12.9 & 12.8 & 12.8 & 12.8 & \begin{tabular}{|l|l|}
12.8 \\
\end{tabular} & 12.8 & 12.8 & 12.8 & 12.8 & 12.7 & 12.7 & \\
\hline & $25 \%$ & 乾球温度 $\left.{ }^{\circ} \mathrm{C}\right)$ & 18.7 & 18.2 & 17.3 & 16.5 & 16.3 & 15.6 & 15.3 & 15.4 & 16.4 & 18.2 & 20.6 & 22.2 & 23.1 & 23.7 & 24.5 & 25.4 & 26.1 & 26.4 & 26.1 & 25.3 & 23.6 & 21.8 & 20.8 & 19.7 & \\
\hline & & 絶対湿度 $\left(\mathrm{g} / \mathrm{kg}^{\prime}\right)$ & 7.9 & 7.8 & 7.8 & 7.8 & 7.7 & 7.7 & 7.7 & 7.6 & 7.5 & 7.6 & 7.6 & \begin{tabular}{l|l}
7.6 \\
\end{tabular} & 7.6 & 7.6 & 7.6 & 7.6 & 7.6 & 7.7 & 7.8 & 7.9 & 7.9 & 8.0 & 8.1 & 8.0 & \\
\hline & & 乾球温度 $\left({ }^{\circ} \mathrm{C}\right)$ & 18.0 & 17.5 & 16.6 & 15.9 & 15.4 & 15.0 & 14.7 & 14.6 & 15.7 & 17.5 & 19.6 & 21.4 & 22.4 & 23.1 & 23.9 & 24.8 & 25.4 & 25.5 & 25.3 & 24.2 & 22.8 & 20.9 & 19.7 & 18.7 & \\
\hline & & 絶対湿度 $\left(\mathrm{g} / \mathrm{kg}^{\prime}\right)$ & 7.7 & 7.7 & 7.6 & 7.6 & 7.5 & 7.5 & 7.5 & 7.4 & 7.4 & 7.4 & 7.4 & \begin{tabular}{l|l|}
7.4 \\
\end{tabular} & 7.4 & 7.4 & 7.4 & 7.4 & 7.4 & 7.4 & 7.5 & 7.6 & 7.6 & 7.7 & 7.8 & 7.8 & \\
\hline & 2 & 乾球温度 ( $\left.{ }^{\circ} \mathrm{C}\right)$ & 29.1 & 28.8 & 28.4 & 28.2 & 28.0 & 28.4 & 29.8 & 30.7 & 31.9 & 33.2 & 34.2 & 34.9 & 35.4 & 35.8 & 35.8 & 35.8 & \begin{tabular}{|l|}
35.2 \\
\end{tabular} & 34.3 & 32.9 & 31.7 & 31.0 & 30.5 & 30.0 & 29.4 & \\
\hline & & 絶対湿度 $\left(\mathrm{g} / \mathrm{kg}^{\prime}\right)$ & 22.3 & 22.1 & 22.0 & 21.9 & 21.7 & 21.8 & 22.0 & 22.2 & 22.3 & 22.3 & 22.3 & 22.3 & 22.1 & 22.0 & 21.8 & 21.9 & 21.9 & 21.9 & 22.1 & 22.5 & 22.4 & 22.5 & 22.6 & 22.4 & 350 \\
\hline & & 乾球温度( $\left.{ }^{\circ} \mathrm{C}\right)$ & 28.6 & 328.2 & 27.8 & 27.7 & 27.6 & 27.9 & 29.2 & 30.1 & 31.4 & 32.6 & 33.5 & 34.2 & 34.8 & 35.0 & 35.1 & 34.9 & 34.3 & 33.3 & 32.2 & 31.1 & 30.5 & 30.0 & 29.5 & 29.0 & \\
\hline & & 絶対湿度 $\left(\mathrm{g} / \mathrm{kg}^{\prime}\right)$ & 21.6 & 21.4 & 21.3 & 21.2 & 21.1 & 21.2 & 21.4 & 21.7 & 21.7 & \begin{tabular}{|l|}
21.7 \\
\end{tabular} & 21.7. & 21.5 & 21.5 & 21.3 & 21.2 & 21.2 & 21.2 & 21.3 & 21.5 & 21.9 & 21.9 & 21.7 & 21.7 & 21. & \\
\hline & & 乾球温度("C) & 28.8 & 28.8 & 29.1 & 28.4 & 28.4 & 29.7 & 30.1 & 31.0 & 32.2 & 33.4 & 34.1 & 34.8 & 35.1 & 35.3 & 35.5 & 35.2 & 34.7 & 33.8 & 32.5 & 31.3 & 31.0 & 30.0 & 29.4 & 29.6 & \\
\hline & & 啛対港 & 21.9 & 22.0 & 22.0 & 21.9 & 21.7 & 21.9 & 22.2 & 22.5 & 22.5 & 22.5 & 22.5 & 22.4 & 22.4 & 22.5 & 22.1 & 22.1 & 22.2 & 22.1 & 22.1 & 22.2 & 22.0 & 22.0 & 22.0 & 21.9 & \\
\hline & & 乾球温度 $\left({ }^{\circ} \mathrm{C}\right)$ & 28.1 & 28.0 & 28.2 & 27.8 & 27.8 & 28.6 & 29.5 & 30.4 & 31.5 & 32.6 & 33.5 & 34.1 & 34.5 & 34.7 & 34.6 & 34.4 & 33.6 & 32.6 & 31.5 & 30.4 & 30.3 & 29.1 & 28.7 & 28.8 & 34.0 \\
\hline & & 絶对湿度 $\left(\mathrm{g} / \mathrm{kg}^{\prime}\right)$ & 21.5 & 21.3 & 21.2 & 21.2 & 21.2 & 21.3 & 21.5 & 21.7 & 21.8 & \begin{tabular}{|l|l|}
21.6 \\
\end{tabular} & 21.7 & 21.8 & 21.6 & 21.6 & 21.6 & 21.5 & 21.5 & 21.5 & 21.6 & 21.6 & 21.5 & 21.5 & 21.4 & 21.5 & \\
\hline & & 乾球温度( $\left.{ }^{\circ} \mathrm{C}\right)$ & 25.5 & 25.2 & 24.8 & 324.8 & 24.7 & 25.2 & 26.3 & 27.1 & 28.1 & 29.5 & 30.5 & 31.3 & 31.8 & 32.1 & 32.1 & 32.1 & 31.5 & 30.6 & 29.7 & 28.5 & 27.7 & 26.8 & 26.1 & 25.7 & \\
\hline & & $\left(\mathrm{g} / \mathrm{kg}^{\prime}\right)$ & 18.3 & 17.9 & 18.0 & 18.0 & 17.9 & 18.1 & 18.2 & 18.5 & 18.7 & 19.0 & 19.0 & 18.9 & 18.8 & 18.7 & 18.8 & 18.9 & 19.1 & $\mid 19.1$ & 18.9 & 18.8 & 18.8 & 18.7 & 18.6 & 18.5 & \\
\hline & & 乾球 & 24.7 & 24.4 & 24.1 & 24.0 & 23.9 & 24.2 & 25.3 & 26.3 & 27.5 & 28.7 & 29.8 & 30.5 & 31.1 & 31.4 & 31.5 & 31.4 & 30.7 & \begin{tabular}{|l|}
29.7 \\
\end{tabular} & 28.7 & 27.7 & 26.8 & 26.1 & 25.5 & 25.0 & 31.4 \\
\hline & & 絶対: & 17.6 & 17.4 & 17.3 & 17.3 & 17.0 & 17.3 & 17.6 & 17.7 & 17.8 & 18.0 & 17.8 & 17.9 & 17.9 & 17.9 & 18.1 & 18.2 & 18.1 & \begin{tabular}{|l|}
18.2 \\
\end{tabular} & 18.2 & 18.0 & 18.0 & 18.1 & 17.9 & 177.8 & \\
\hline & & 乾球温度 ( $\left.{ }^{\circ} \mathrm{C}\right)$ & 27.2 & 27.2 & 26.8 & 26.7 & 26.6 & 26.7 & 27.5 & 28.3 & 29.4 & 30.7 & 31.8 & 32.7 & 33.7 & 34.1 & 34.4 & 34.4 & 34.0 & 33.3 & 32.0 & 30.6 & 29.3 & 27.9 & 27.2 & 27.1 & \\
\hline & & 絶対湿度 $\left(\mathrm{g} / \mathrm{kg}^{\prime}\right)$ & 19.8 & 39.8 & 19.8 & 19.7 & 19.7 & 19.7 & 19.7 & 19.9 & 20.1 & 20.1 & 20.0 & 20.1 & 20.2 & 20.1 & 20.2 & 20.1 & 20.2 & 20.3 & 20.4 & 20.2 & 20.1 & 19.9 & 19.8 & 19.8 & \\
\hline & & 乾球 & 26.7 & 26.6 & 26.3 & $\begin{array}{l}326.1 \\
\end{array}$ & 26.0 & 26.1 & 27.0 & 27.6 & 28.9 & 30.1 & 31.2 & 32.1 & 32.8 . & 33.1 & 33.3 & 33.5 & 33.1 & 32.4 & 31.2 & 29.7 & \begin{tabular}{|l|l|}
28.6 \\
\end{tabular} & 27.5 & 26.7 & 26.5 & \\
\hline & & 絶対 & 19.3 & 19.3 & 19.2 & 219.1 & 18.9 & 19.0 & 19.1 & 19.2 & 19.3 & \begin{tabular}{|l|}
19.2 \\
\end{tabular} & 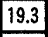 & 19.2 & 19.1 & 19.2 & 19.1 & 19.0 & 19.1 & \begin{tabular}{|l|}
19.3 \\
\end{tabular} & 19.5 & 19.3 & 19.2 & 19.2 & 19.3 & 19.3 & \\
\hline & & 乾球 & 26.5 & 526.0 & 25.2 & $2 \longdiv { 2 4 . 7 }$ & 24.5 & 524.1 & 23.6 & 23.6 & 24.9 & 27.2 & 29.8 & 31.6 & 32.6 & 33.0 & 33.4 & 33.9 & 34.0 & 34.0 & 33.8 & 32.9 & 31.6 & 29.6 & 28.4 & 27.5 & \\
\hline & & 絶対湿度 $\left(\mathrm{g} / \mathrm{kg}^{\prime}\right)$ & 9.7 & 9.7 & 9.8 & 9.8 & 9.8 & 9.8 & 9.8 & 9.7 & 9.6 & \begin{tabular}{l|l|}
9.5 \\
\end{tabular} & 9.5 & \begin{tabular}{ll|}
9.4 \\
\end{tabular} & 9.3 & 9.2 & 9.3 & 9.4 & 9.3 & 9.2 & 9.1 & 9.3 & 9.4 & 9.5 & 9.7 & 9.8 & \\
\hline & $50 \%$ & 乾球湿 & 25.4 & 24.7 & 24.0 & 0 & 23.3 & 32.8 & 22.8 & 22.8 & 24.1 & 26.5 & 29.0 & 30.6 & 31.5 & 31.9 & 32.4 & 32.9 & 33.3 & 33.2 & 32.9 & 32.0 & 30.6 & 28.8 & 27.8 & 26.7 & \\
\hline & & 絶対㨽 & 9.3 & 9.3 & 9.3 & 9.3 & 9.2 & 9.3 & 9.2 & 9.2 & 9.1 & \begin{tabular}{|l|}
9.1 \\
\end{tabular} & 9.0 & 8.9 & 8.8 & 8.6 & 8.7 & 8.7 & 8.6 & 8.6 & 8.6 & 8.7 & 8.8 & 9.0 & 9.3 & 9.3 & \\
\hline & & 竛 & 30.0 & 29.8 & 29.3 & 329.2 & 29.1 & 29.3 & 30.4 & 31.3 & 32.4 & 33.6 & 34.5 & 35.1 & 35.6 & 36.1 & 36.3 & 36.3 & 35.9 & 35.0 & 33.7 & 32.5 & 31.9 & 31.4 & 30.9 & 30.3 & \\
\hline & & 絶対湿度 $(\mathrm{g} / \mathrm{kg})$ & 22.6 & 22.5 & 22.4 & \begin{tabular}{l|l}
4 & 22.3 \\
\end{tabular} & 22.2 & 22.3 & 22.4 & 22.5 & 22.4 & 22.3 & 22.1 & \begin{tabular}{|l|}
22.2 \\
\end{tabular} & 22.2 & 22.1 & 22.2 & 22.2 & 22.3 & 22.4 & 22.7 & 22.8 & 22.7 & 2.9 & 22.8 & 22.7 & \\
\hline & & 乾球: & 29.4 & 29.2 & 28.8 & \begin{tabular}{l|l}
828.7 \\
\end{tabular} & 28.6 & 628.8 & 30.0 & 30.7 & 31.8 & 32.8 & 33.7 & \begin{tabular}{|l|}
34.3 \\
\end{tabular} & 34.7 & 35.1 & 35.3 & 35.4 & 35.0 & 34.0 & 32.7 & 31.6 & 31.0 & 30.6 & 30.3 & 29.7 & \\
\hline & & 秝対视 & 2.0 & 21.9 & 21.9 & 921.7 & 21.6 & 621.7 & 21.8 & 21.9 & 21.6 & 21.6 & 21.7 & \begin{tabular}{|l|}
21.6 \\
\end{tabular} & 21.6 & 21.6 & 21.6 & 21.6 & 21.6 & 21.8 & 22.0 & 22.3 & 22.3 & 22.2 & 22.1 & 22.0 & \\
\hline & & & 28.8 & 28.5 & 27.8 & & & 426.3 & 27.0 & 27.7 & 29.0 & 30.4 & 32.1 & 33.4 & 34.3 & & 35.8 & 36.4 & 36.4 & 35.7 & 34.4 & 32.8 & 31.9 & 30.7 & 30.0 & 29.3 & \\
\hline & & 绝対湿 & 18.2 & 17.8 & 17.7 & $\begin{array}{l}717.7 \\
\end{array}$ & 17.6 & 6 & 17.9 & 18.0 & 18.2 & 18.5 & 18.5 & 18.8 & 18.8 & 18.6 & 18.6 & 18.7 & 18.6 & 18.6 & 18.8 & 19.1 & 18.9 & 18.7 & 18.6 & 18.3 & \\
\hline & & 乾球温度 ( $\left.{ }^{\circ} \mathrm{C}\right)$ & 27.8 & 27.4 & 26.7 & $\begin{array}{l}726.1 \\
\end{array}$ & 25.6 & 25.5 & 26.1 & 26.5 & 28.0 & 29.7 & 31.3 & 32.5 & \begin{tabular}{|l|l}
33.6 \\
\end{tabular} & 34.4 & 35.1 & 35.6 & 35.4 & 34.7 & 33.5 & 32.1 & 31.1 & 29.9 & 29.1 & 8.4 & \\
\hline & & 絶刘涪 & 17.4 & 17.2 & 17.1 & 177.0 & 16.8 & 816.9 & 17.0 & 17.0 & 17.4 & 17.5 & 17.7 & 17.8 & 17.9 & 17.8 & 17.6 & 17.7 & 177.8 & 18.0 & 18.1 & 18.4 & 18.2 & 18.0 & 17.8 & 17.6 & \\
\hline & & & 28.0 & 27.8 & & 326.9 & 26.7 & 26.9 & & 29.0 & 30.4 & 32.0 & 33.3 & \begin{tabular}{|l|}
34.2 \\
\end{tabular} & 35.0 & 35.6 & 36.0 & 36.1 & 35.5 & 34.4 & 32.9 & 31.6 & 30.8 & 29.8 & 29.1 & 28.4 & \\
\hline & & $\left(\mathrm{g} / \mathrm{kg}^{\prime}\right)$ & 20.6 & 20.4 & 20.2 & $2 \longdiv { 2 0 . 1 }$ & 19.9 & 20.2 & 20.5 & 20.7 & 21.0 & 21.0 & 21.1 & \begin{tabular}{|l|}
21.2 \\
\end{tabular} & 21.5 & 21.6 & 21.5 & 21.5 & 21.4 & 21.5 & 21.6 & 21.6 & 21.4 & & 21.1 & 20.7 & \\
\hline & & 乾球温度 $\left({ }^{\circ} \mathrm{C}\right)$ & 27.2 & 26.9 & 26.3 & $3 \longdiv { 2 6 . 1 }$ & 26.0 & 26.1 & 27.2 & 28.0 & 29.5 & 31.2 & 32.5 & 33.5 & 34.2 & 34.9 & 35.2 & 35.2 & 34.7 & 33.5 & 32.1 & 30.6 & 29.7 & 8.9 & & 7.7 & \\
\hline & & 觗対湿度 $(\mathrm{g} / \mathrm{kg}$ & 19.8 & 19.6 & 19.5 & \begin{tabular}{l|l}
5 & 19.5 \\
\end{tabular} & 19.2 & 19.5 & 19.7 & 19.8 & 20.0 & 20.2 & 20.3 & 20.3 & 20.3 & 20.1 & & 202 & 204 & 20.6 & 20.6 & 0.6 & & & & & \\
\hline
\end{tabular}


して 1 月の暖房負荷と 7 月の冷房負荷をシミュレーションした。図 3 と図 4 には，それぞれ 1 月と 7 月における各時の各気象要素月平 均値による空調負荷と標準年気象デー夕によるものの比較を示す。 図 1 と図 2 に示す相関関係と比べ, 解析期間(1982 1997 年)におけ る時刻別の各気象要素平均值の方が摽準年気象デー夕による負荷と の相関係数が低い。また，偏差の絶対值を表す RSME (二次平均誤差) では図 3 と図 4 は図 1 . と図 2 のそれぞれ 7.1 倍と 1.8 倍となる。前 述の理由で, 解析期間における時刻別月平均気象デ一夕(後述の標準 日気象データ)による月積算負荷をその住宅の月積算空調負荷の累 年平均値之認めれば，標準年気象デー夕による月積算空調負荷の累 年平均値の推定は誤差がやや大きいと言えよう。その原因は, 標準 年気象データ中の標準月の各気象要素月平均值が必ずしもその累年 平均値と一致しないためと考えられる。

\section{3-2 標準日気象データの作成}

前節で述べたように, 時刻別各気象要素の月平均値による空調負 荷は標準年気象デー夕より空調負荷の累年平均値を反映しているた め, 本研究ではこのような解析期間における時刻別各気象要素の月 平均值をその月の標準日気象データと呼ぶことにする。表 1 に示す 各都市において，解析期間(1982 1997 年)における時刻ごとの各気 象要素の月平均値を求め, この 24 時間分の気象デー夕をその地方の 標準日気象デー夕とした。本論文では, 紙面の関係で表 1 に示す 46 都市のうちの 17 都市について表 $2(1$ 月)と表 $3(7$ 月)に示す。 1 月と 7 月以外の月の標準日気象データや，他の都市の標準日気象データ については, ウェブページ等で公表する予定である。

以上の論述をまとめると, 標準年気象デー夕と比べ, 標準日気象 デー夕には以下の長所がある。(1)簡潔でその地方の気候特性(各気象 要素の最高值, 最低値と日変動パターン)を表している。(2)それを用 いて空調負荷の月積算值を求めるとき, 標準年気象デー夕より空調 負荷の累年平均值に近い結果を得ることができる。(3)標準年気象デ 一タを用いたシミュレーションに比ベ, 標準日気象デー夕によるそ れの方が計算時間を大幅に短縮させることができる。標準日気象デ 一夕を用いて空調負荷のシミュレーションを行う際, 非定常伝熱計 算のため, 助走計算期間が必要であるものの, 日周期の周期定常状 態にさえ達せば，1日の結果で月積算負荷を推定することができる ので，計算時間の短縮が図れる。

しかし，標準年気象デー夕は意味がなくなるわけではない。月単 位ではなく，任意期間における建物のシミュレーションを行う場合 における標準年気象デー夕の必要性は言うまでもない。

\section{4. 暖冷房設備設計用気象データ}

\section{4-1 暖房設計用気象データ}

前章で述べた標準日気象デー夕は標準年気象データと同様, 年間 シミュレーション用気象データであり, 暖冷房設備設計用気象デー タではない。暖冷房設備設計用気象デー夕は最大負荷を算出するた めに, 超過確率曲線による時刻別 $\mathrm{TAC}($ 危険率)温度および湿度が必 要になってくる 9)。現在, 中国の主要都市における冬季および夏季 の設備設計用温度と湿度が設計規範として決まっているが，その危 険率が明らかでないだけでなく, 外気温度の日変動パターンも不明 である。本研究では，解析期間(1982 1997 年)の観測デー夕に基づ
いて 1 時間に補完した気象データを統計処理し，表 1 に示す 46 都 市の設計用気象データを作成して, そのうちの 17 都市の暖房設計用 気象データを表 4 に示す。危険率は $2.5 \%$ と $5.0 \%$ の 2 とおりである。 危険率を求める際, 文献 ${ }^{9)}$ を参考にして，6 月〜9 月を夏季， 12 月〜 3 月を冬季としている。表 4 の右端に示す中国現行暖房設計温度 ${ }^{4)}$ 法各都市とも危険率 $5 \%$ \%最低温度に近く，日本で多く用いられる 危険率 $2.5 \%$ 温度より高い。このことは中国の建築物はレンガや RC といった熱容量の大きい材料を多く使用しているため, 設計基淮が 緩やかであることを示唆している。

\section{4-2 冷房設計用気象データ}

表 5 は各主要都市における危険率 $2.5 \%$ と $5.0 \%$ 時の冷房設計温度 である。ラサを除いて，右端に示す現行中国冷房設計温度は危険率 $5.0 \%$ の最高温度に近い。ラサでは, 現行設計温度は危険率 $5.0 \%$ より $2.7^{\circ} \mathrm{C}$ 低い。それはラサの夏季における温度日較差の大きさや湿 度の低さを加味しているためと推測される。

\section{5. 終わりに}

本論文で得た知見をまとめると，次のとおりである。

(1) $5^{\circ} \mathrm{C}, 10^{\circ} \mathrm{C}, 15^{\circ} \mathrm{C}$ 開始温度とした暖房ディグリーデーおよび $23^{\circ} \mathrm{C}$ 開始温度とした冷房ディグリーアワーを求めた。

（2）空調負荷の月積算值を求める場合，標準年気象データの時刻別 における各気象要素の月平均值で標準年気象データを代替できるこ とを明らかにした。

（3）時刻別各気象要素の月平均值をその月の標準日気象データと 呼ぶことにし，主要都市における標準日気象データを作成した。

（4）補完された観測気象データに基づいて，中国主要都市における 危険率別の暖冷房設計温度を作成した。

\section{参考文献}

1）張 晴原, 浅野筫二; 中国主要都市の標準年気象データに関する研究, 日本 建築学会計画系論文集, No.543, pp.65-70, 2001 年 5 月

2）張 睛原, 浅野賢二, 林 徽夫, 今井 計: 中国の暖房負荷の地域特性, 日本 建築学会計画系論文集, No.548, pp.69-74, 2001 年 10 月

3) Q. Zhang, et al: Regional Chatacteristics of Air-Conditioning Loads for Residences in China, Proceedings of the $7^{\text {th }}$ International IBPSA Conference (Rio de Janeiro), pp.645-652, 2001

4）中華人民共和国基準 采暖通風与空気調節設計規範, p.51, 1988

5）松尾陽, 横山浩一, 石野久彌, 川本昭吾 : 空調設備の動的熱負荷計算入門, 日本建築設備士協会

6）日本建築学会(赤坂,他執筆): 拡張アメダス気象データ,丸善,第 1 版, 2000 年 7) 節能住宅設計実例図集編集委員会: 節能住宅設計実例図集, 中国建築工業 出版社, p. 9,1999 年

8）住宅·建築省エネルギー機構 住宅の次世代省エネルギー基準, p.59, 平成 11 年

9）空気調和·衛生工学会: 空気調和·衛生工学便筧 第 2 巻, p.17, 丸善, 1996 年 （2001年10月 1 日原稿受理，2002年 2 月 14 日採用決定 